\title{
DESEMPENHO DA CULTURA DE MILHO (Zea mays L.) SUBMETIDA A DIFERENTES HERBICIDAS NA AUSÊNCIA DE PLANTAS DANINHAS
}

\section{RAMIRO FERNANDO LÓPEZ OVEJERO \\ Engenheiro Agrônomo}

Orientador: Prof. Dr. Durval Dourado-Neto

\begin{abstract}
Dissertação apresentada à Escola Superior de Agricultura "Luiz de Queiroz", Universidade de São Paulo, para a obtenção do titulo de Mestre em Agronomia, Área de Concentração: Fitotecnia.
\end{abstract}

PIRACICABA

Estado de São Paulo - Brasil

Outubro -2000 


\title{
Dados Internacionais de Catalogaçāo na Publicaçāo (CIP) DIVISÃO DE BIBLIOTECA E DOCUMENTAÇÃO - Campus "Luiz de Queiroz"/USP
}

\author{
López Ovejero, Ramiro Femando \\ Desempenho da cultura de milho (Zea mays L.) submetida a diferentes herbicidas \\ na ausência de plantas daninhas / Ramiro Femando López Ovejero. - - Piracicaba, \\ 2000. \\ 46 p. : il. \\ Dissertação (mestrado) - - Escola Superior de Agricultura Luiz de Queiroz, 2000. \\ Bibliografia. \\ 1. Controle quimico 2. Fenologia 3. Fitotoxicidade 4. Herbicida 5. Milho 6. Planta \\ daninha 7. Rendimento I. Título
}

$\operatorname{CDD} 633.15$

\section{Permitida a cópia total ou parcial deste documento, desde que citala a foute - 0 autor"}


Aos meus pais (Joaquin e Marta), e a minha esposa (Eliana),

\section{OFEREÇO}

A meu avô (Roque)

DEDICO 


\section{AGRADECIMENTO}

- Aos meus pais pelo esforço, compreensão e apoio em todas as fases de minha vida;

- À minha esposa pelo amor, estímulo e permanente companhia;

- Aos meus sogros pelo apoio e oportunidade;

- Ao Professor Antonio Luiz Fancelli pela orientação, amizade, colaboração, oportunidade e pelas suas contribuições a minha formação profissional;

- Ao Professor Durval Dourado-Neto pela orientação;

- À CAPES, pela bolsa de estudo fornecida para a realização deste trabalho;

- Aos Engenheiros Agrônomos e colegas Hugo Vocurca e Márcio Augusto

Soares, pela valiosa colaboração prestada durante a fase experimental do trabalho;

- Aos Engenheiros Agrônomos, colegas e amigos Axel García y García e Marcela dos Santos Müller pela importante colaboração prestada na fase de redação final deste trabalho; e

- Aos funcionários do Departamento de Produção Vegetal pela sua colaboração na fase experimental, sem a qual este trabalho não poderia ter sido realizado. 


\section{SUMÁRIO}

Página

LISTA DE FIGURAS

VII

LISTA DE TABELAS

VIII

LISTA DE QUADROS

IX

LISTA DE SÍMBOLOS

$\mathbf{x}$

RESUMO

$\mathbf{X I}$

SUMMARY

XII

RESUMEN

XIII

1 INTRODUÇÃO

2 REVISÃO DE LITERATURA

2.1 Importância da cultura

2.2 Fenologia do milho

2.3 Rendimento de grãos

2.4 Momento de aplicação dos herbicidas em pós-emergência

2.5 Herbicidas de pós-emergência

3 MATERIAL E MÉTODOS 
3.1 O local do experimento

3.2 A cultura de milho

3.3 Condução da cultura

3.4 Herbicidas, tratamentos e método de aplicação

3.5 Delineamento experimental

3.6 Características avaliadas

3.6.1 Caracteres agronômicos

3.6.2 Componentes da produção

4 RESULTADOS E DISCUSSÃO

4.1 Caracteres agronômicos

4.1.1 Fenologia

4.1.2 Sintomas de fitotoxidez

4.1.3 Área Foliar

4.1.4 Altura de planta

4.1.5 Altura de inserção da espiga

\subsection{Componentes da produção}

4.2.1 População

4.2.2 Prolificidade

4.2.3 Comprimento da espiga

4.2.4 Número de fileiras por espiga 28

4.2.5 Número de grãos por fileira

4.2.6 Massa de 1000 grãos

4.2.7 Rendimento de grãos 
5 CONCLUSÕES

6 ANEXO: ANÁLISE ESTATÍSTICA

REFERÊNCIAS BIBLIOGRÁFICAS

7 APÊNDICE 


\section{LISTA DE FIGURAS}

Página

Figura 1. Variação do número de fileiras por espiga (Nf) referente aos diferentes tratamentos.

Figura 2. Variação do número de grãos por fileira (Gf) referente aos diferentes tratamentos.

Figura 3. Variação da massa $(\mathrm{Mg}$, g) de 1000 grãos referente aos diferentes tratamentos.

Figura 4. Variação do rendimento médio de grãos $(\mathrm{Rg}, \mathrm{kg} / \mathrm{ha})$ referente aos diferentes tratamentos.

Figura 5. Área dessecada antes da semeadura, no sistema de plantio direto. Departamento de Produção Vegetal, ESALQ/USP.

Figura 6 Semeadura da cultura de milho (híbrido Pioneer 3027), no sistema de plantio direto.

Figura 7 Aplicação dos herbicidas quando a cultura de milho apresentava duas folhas (estádio 0-1).

Figura 8 Aplicação dos herbicidas quando a cultura de milho apresentava quatro folhas (estádio 1).

Figura 9 Aplicação dos herbicidas quando a cultura de milho apresentava oito folhas (estádio 2).

Figura 10 Visão da área experimental quando a cultura de milho se apresentava no florescimento. 


\section{LISTA DE TABELAS}

Página

Tabela 1. Características agronômicas.

Tabela 2. Componentes de produção.

Tabela 3. Análise de variância referente à área foliar $\left(\mathrm{cm}^{2}\right)$. 35

Tabela 4. Análise de variância referente à Altura de planta $(\mathrm{cm})$. 35

Tabela 5. Análise de variância referente à altura de Inserção da espiga $(\mathrm{cm}) . \quad 35$

Tabela 6. Análise de variância referente ao comprimento de espiga $(\mathrm{cm}) \quad 36$

Tabela 7. Análise de variância referente ao número de fileiras por espiga. $\quad 36$

Tabela 8. Análise de variância referente ao número de grãos por fileira. 36

Tabela 9. Análise de variância referente à massa de 1000 sementes $(\mathrm{g})$. 36

Tabela 10. Análise de variância referente ao rendimento de grãos (kg/ha). $\quad 37$ 


\section{LISTA DE QUADROS}

Página

Quadro 1. Descrição sucinta dos estádios fenológicos da cultura de milho (Fancelli, 1986).

Quadro 2. Descrição sucinta dos tratamentos.

Quadro 3. Caracteres agronômicos avaliados no experimento.

Quadro 4. Componentes da produção avaliados no experimento.

Quadro 5. Escala European Weed Research Council (EWRC, 1964).

Quadro 6. Fenologia.

Quadro 7. Sintomas de fitotoxidez. 


\title{
LISTA DE SÍMBOLOS
}

\author{
Símbolo \\ Descrição \\ $\mathrm{cm} \quad$ Centímetro \\ DAA Dias Após a Aplicação (do herbicida) \\ DAT Dias Após o Tratamento (com o herbicida) \\ EMBRAPA Empresa Brasileira de Pesquisa Agropecuária \\ g Grama \\ ha Hectare $\left(10.000 \mathrm{~m}^{2}\right)$ \\ i.a. Ingrediente ativo \\ kg Quilograma \\ L Litro \\ n.s. Nivel de significância \\ m Metro \\ p.c. Produto comercial \\ PósE Pós-emergência \\ PPI Pré-plantio incorporado \\ PréE Pré-emergência
}




\section{DESEMPENHO DA CULTURA DE MILHO (Zea mays L.) SUBMETIDA A DIFERENTES HERBICIDAS NA AUSÊNCIA DE PLANTAS DANINHAS}

Autor: Ramiro Fernando López Ovejero Orientador: Prof. Dr. Durval Dourado-Neto

\section{RESUMO}

Com o objetivo de avaliar o efeito fitotóxico dos herbicidas aplicados em pré e pós-emergência na cultura de milho em plantio direto, mantendo as parcelas experimentais totalmente no limpo, foram realizadas avaliações visuais aos 7, 14 e 21 dias após aplicação dos mesmos, adotando a escala da European Weed Research Council (EWRC, 1964). Para isso, foi semeado o híbrido Pioneer 3027, no gual foram realizadas aplicações com os seguintes princípios ativos: (i) Atrazine + Metolachlor (PréE), (ii) Atrazine + Metolachlor + Nicosulfuron (PósE), (iii) Nicosulfuron (PósE), (iv) Nicosulfuron + Atrazine (PósE), (v) Atrazine + óleo vegetal (PósE) e (vi) Atrazine + Simazine (PósE), quando a planta apresentou 2 (estádio 0-1), 4 (estádio 1) e 8 folhas (estádio 2). O delineamento experimental foi em blocos casualizados com vinte e dois tratamentos e três repetições. Determinou-se o efeito dos herbicidas sobre a fenologia, população, altura de planta, área foliar e nos componentes do rendimento da cultura. Concluiu-se que: (i) os danos dependem dos ingredientes ativos, da dosagem e do estádio fenológico da cultura; (ii) a duração dos estádios fenológicos da cultura de milho não é afetada pelos herbicidas utilizados; (iii) os herbicidas não provocam alterações morfológicas e não comprometem área foliar, porém, quando aplicados no estádio fenológico 2 ( 8 folhas), reduzem o rendimento devido à alteração do número de fileiras por espiga, número de grãos por fileira, e massa de 1000 grãos; e (iv) o manejo químico de plantas daninhas na cultura de milho deve ser efetuado, com segurança, até 4 folhas (estádio 1), para evitar danos por fitotoxicidade pelos herbicidas e competição por água, nutrientes e luz. 


\section{MAIZE (Zea mays L.) CROP PERFORMANCE UNDER THE APPLICATION OF DIFFERENT HERBICIDES IN A WEED-FREE SYSTEM}

Author: Ramiro Fernando López Ovejero Adviser: Prof. Dr. Durval Dourado-Neto

\section{SUMMARY}

With the purpose of evaluating the toxic effect of pre and postemergence herbicides on the maize crop using the no tillage system, all experimental plots were kept free of weeds, and a visual evaluation was performed at 7, 14, and 21 days after each application of herbicide adopting the European Weed Research Council scale (EWRC, 1964). The maize hybrid Pioneer 3027 was sowed, and the following herbicides were applied when the plants presented 2 (stage 0), 4 (stage 1), and 8 leaves (stage 2): (i) Atrazine + Metolachlor (PreE), (ii) Atrazine + Metolachlor + Nicosulfuron (PostE), (iii) Nicosulfuron (PostE), (iv) Nicosulfuron + Atrazine (PostE), (v) Atrazine + vegetable oil (PostE) and (vi) Atrazine + Simazine (PostE). The experimental design consisted of randomized blocks with twenty two treatments and three replications. The effects of the herbicides on the phenological stages, plant population, plant height, leaf area, and crop yield components were evaluated. The results supported the following conclusions: (i) the crop damage depended on the herbicide active ingredients, dosage and crop phenological stage at the time of herbicide application; (ii) the herbicides did not affect the duration of the each crop phenological stage; (iii) the herbicides did not cause any morphological variation and did not reduce leaf area, even though, when applied at the second phenological stage (8 leaves), all herbicides caused a reduction in grain yield, due to a decrease in total number of grain rows per ear, total number of grains per row, and mass of 1,000 grains; and (iv) the herbicide management must be performed until stage 1 (4 leaves) to prevent toxic damages and competition for water, nutrients and light. 


\title{
DESEMPEÑO DEL CULTIVO DE MAÍZ (Zea mays L.) SOMETIDO A DIFERENTES HERBICIDAS EN AUSENCIA DE MALEZAS
}

\author{
Autor: Ramiro Fernando López Ovejero \\ Director: Prof. Dr. Durval Dourado-Neto
}

\section{RESUMEN}

Con el objetivo de estudiar el efecto fitotóxico de los herbicidas aplicados en pre y post-emergéncia en el cultivo de maíz en siembra directa, manteniendo las parcelas experimentales completamente limpias, fueron realizadas evaluaciones visuales a los 7,14 y 21 dias despues de la aplicación de los mismos, adoptando la escala de la European Weed Research Council (EWRC, 1964). Para eso, fue sembrado el híbrido de maíz Pioneer 3027 , realizando aplicaciones con los seguintes principios activos: (i) Atrazine + Metolachlor (PreE), (ii) Atrazine + Metolachlor + Nicosulfuron (PostE), (iii) Nicosulfuron (PostE), (iv) Nicosulfuron + Atrazine (PostE), (v) Atrazine + óleo vegetal (PostE) e (vi) Atrazine + Simazine (PostE), cuando la planta presentava 2(estado 0-1), 4 (estado 1) y 8 hojas (estado 2). El diseño experimental fue en bloques al acaso con 22 tratamentos y tres repeticiones. El efecto de los herbicidas fue determinado en la fenología, población, altura de la planta, área foliar y en los componentes del rendimento. Concluyese que: (i) los daños dependen de los ingredientes activos, de la dosis y del estado fenológico del cultivo; (ii) la duración de los estados fenológicos del cultivo de maíz no fueron afectados por los herbicidas utilizados; (iii) los herbicidas no provocan alteraciones morfológicas y no comprometen el área foliar, siendo que, cuando aplicados en el estado fenológico 2 ( 8 folhas) reducen el rendimento debido a la alteración del número de hileras por espiga, número de granos por hilera, y la masa de 1000 granos; y (iv) el manejo químico de malezas en el cultivo de maíz debe ser efectuado con seguridad hasta las 4 hojas (estado 1) para evitar daños por fitotoxicidad y competición por agua, nutrientes y luz. 


\section{INTRODUÇÃO}

A redução do rendimento da cultura devido à competição estabelecida com as plantas daninhas pode alcançar até $70 \%$, em função da espécie, do grau de infestação, do tipo de solo, das condições climáticas reinantes no período, além do estádio fenológico da cultura (Fancelli \& Dourado-Neto, 2000).

Segundo Silva (1993), as perdas de rendimento de milho provocadas pelas plantas daninhas podem variar de 10 a $84 \%$, com valor médio de $47 \%$. Sendo assim, em um sistema de produção em que é esperado um rendimento de 100 sacos de milho por hectare, 47 são perdidos devido à competição das plantas daninhas.

Portanto, o controle de plantas daninhas é uma necessidade de ordem econômica, sendo que pela escassez e conseqüente elevado custo da mão-deobra, é necessária a utilização do método químico, o qual, devido a sua elevada eficiência, permite a execução dessa operação agrícola em tempo oportuno e de forma satisfatória.

O método químico é representado pelo uso de herbicidas, cuja eficiência de controle é dependente de fatores técnicos, econômicos e climáticos.

No Brasil, a área cultivada com milho e tratada com herbicidas aumentou de 750.000 ha em 1987 para 1.347 .000 ha em 1991, e para 2.800 .000 ha em 1995. Em termos relativos, o crescimento mencionado passou de $5,7 \%$ para $22,4 \%$ da área colhida, num período de oito anos. Em 1996, a estimativa era que $25 \%$ da área cultivada com milho seria tratada com herbicidas, ultrapassando 3.000.000 ha (Silva \& Duarte, 1997). 
Contudo, sob determinadas condições edafoclimáticas e, dependendo do hibrido de milho semeado, alguns ingredientes ativos presentes nos herbicidas podem causar efeito fitotóxico sobre as plantas, com a conseqüência de provocar danos fisiológicos às plântulas e afetar 0 estabelecimento da cultura. Em decorrência desse fato, o rendimento planejado pode não ser atingido.

Nesse contexto, o herbicida a ser empregado deve ser preferencialmente seletivo para a cultura não causando injúrias às plantas de milho, tanto na parte aérea quanto no sistema radicular, visto que inúmeras condições de uso podem causar distintos efeitos fitotóxicos.

Por essa razão, mostra-se de fundamental importância a avaliação, em condições de campo, da influência dos principais herbicidas aplicados em pósemergência sobre o desempenho da cultura de milho, independente da sua eficiência no controle de plantas daninhas.

O presente trabalho teve por objetivo avaliar o efeito fitotóxico dos ingredientes ativos presentes nos herbicidas estudados (recomendados para a cultura de milho de forma individualizada ou combinada e em diferentes dosagens) no desempenho da cultura de milho, em sistema de plantio direto, avaliado pelas alterações morfológicas e fenológicas e pelos componentes do rendimento. 


\section{REVISÃO DE LITERATURA}

\subsection{Importância da cultura}

Historicamente, o milho sempre representou uma das principais culturas da agricultura brasileira, não somente no aspecto quantitativo, como também no que diz respeito à sua importância estratégica por ser a base da alimentação animal e, conseqüentemente, humana.

Os números da safra 1999/2000 são bastante representativos para ilustrar a afirmação anterior. O Brasil produziu 34 milhões de toneladas desse grão, numa área de 12,2 milhões de hectares. Considerando nessa mesma safra uma área agrícola de aproximadamente 52 milhões de hectares, o milho representou $23,5 \%$ da área colhida, e aproximadamente, $42 \%$ dos grãos produzidos no país (FNP CONSULTORIA, 2000).

Se, por um lado, a produção nacional no cenário internacional representa cerca de $6 \%$ do total produzido no mundo $(511,5$ milhões de toneladas), por outro lado, a produtividade média brasileira encontra-se muito aquém do desejável, pois o Brasil ocupa $9 \%$ da área mundial colhida com o referido grão, com uma média nacional corresponde a $2.780 \mathrm{~kg} / \mathrm{ha}$. Trata-se de um valor muito abaixo dos $4.385 \mathrm{~kg} / \mathrm{ha}$, que representa a média de produtividade dos 22 principais países produtores desse cereal.

\subsection{Fenologia do milho}

A cultura de milho está sujeita a uma série de fatores bióticos ou abióticos que alteram a fisiologia e a morfologia da planta e, conseqüentemente, reduzem o rendimento e a qualidade do produto. Os 
distúrbios abióticos são causados, dentre outros, por agentes como temperatura, deficiência nutricional, fitotoxidez causada por substâncias químicas, fertilizantes e estresse hídrico. Os distúrbios bióticos (doenças infecciosas) são causados por fungos, bactérias, vírus, micoplasmas e nematóides (Silva \& Menten, 1997). Sendo assim, todos esses fatores deverão ser considerados no planejamento e no manejo da cultura.

O milho é uma planta de ciclo vegetativo variável, sendo que nas condições brasileiras, a cultura apresenta ciclo entre 110 e 180 dias (período esse compreendido entre a semeadura e a colheita), em função da caracterização dos híbridos (superprecoce, precoce e normal).

De forma geral, o ciclo da cultura compreende as seguintes etapas de desenvolvimento (Fancelli \& Dourado-Neto, 1997a): (i) germinação e emergência: período compreendido desde a semeadura até o efetivo aparecimento da plântula, o qual, em função da temperatura e umidade do solo, pode compreender 5 a 12 dias de duração; (ii) crescimento vegetativo: período compreendido entre a emissão da segunda folha e o início do florescimento. Tal etapa apresenta extensão variável, sendo esse fato comumente empregado para caracterizar os tipos de híbridos de milho, quanto ao comprimento do ciclo; (iii) florescimento: período compreendido entre o início da polinização e o início da frutificação, cuja duração raramente ultrapassa 10 dias; (iv) frutificação: período compreendido até o enchimento completo dos grãos, sendo sua duração estimada entre 40 a 60 dias; e (v) maturação: período compreendido entre o final da frutificação e o aparecimento da camada negra na base do grão, sendo esse relativamente curto e indicativo do final do ciclo de vida da planta.

Essas etapas podem ser divididas em onze estádios distintos de desenvolvimento para facilitar o manejo (fenologia é utilizável por ser uma referência exata) e o estudo da cultura, conforme Quadro 1 (Fancelli, 1986). 
Quadro 1. Descrição sucinta dos estádios fenológicos da cultura de milho (Fancelli, 1986).

\begin{tabular}{|c|c|}
\hline Estádio & Evento \\
\hline 0 & Germinação e emergência \\
\hline 1 & Planta com 4 folhas \\
\hline 2 & Planta com 8 folhas \\
\hline 3 & Planta com 12 folhas \\
\hline 4 & Emissão do pendão \\
\hline 5 & Florescimento \\
\hline 6 & Grãos leitosos \\
\hline 7 & Grãos pastosos \\
\hline 8 & Grãos em formação de dentes \\
\hline 9 & Grãos dentados \\
\hline 10 & Maturidade fisiológica \\
\hline
\end{tabular}

\subsection{Rendimento de grãos}

Segundo Dourado-Neto \& Fancelli (1997), o rendimento de grãos $(\mathrm{kg} / \mathrm{ha})$ depende da população, prolificidade, número médio de fileiras de grãos por espiga (sempre em número par), número médio de grãos por fileira e a massa média por unidade de grão (ou semente).

A população e prolificidade devem ser otimizadas considerando-se a arquitetura da planta, condições edafoclimáticas e tecnologia empregada.

No estádio 0 , uma semana após a emergência, a plântula apresenta-se com duas folhas totalmente expandidas, encontrando-se a partir dessa fase apta a iniciar o processo fotossintético.

O estádio 1 , normalmente coincide com a segunda semana após a emergência da planta, ocorrendo nesse período a diferenciação do meristema apical, cujas estruturas ainda se encontram localizadas abaixo da superfície do solo. O processo de diferenciação floral inicia nesse estádio, o qual origina os 
primórdios da panícula e da espiga, bem como define o potencial de produção (Fancelli \& Dourado-Neto, 1997a). Esse período pode se estender até a sexta folha, dada a natureza protândrica dos principais genótipos utilizados no Brasil. Três semanas após a emergência das plantas (6 folhas) a região de crescimento atinge a superfície do solo.

O número de fileiras por espiga é definido entre os estádios fenológicos 2 a 3, aproximadamente um mês após a emergência, e o número médio de grãos por fileira é afetado pelo tamanho da espiga, a qual é definida, principalmente, entre os estádios 3 e 5 (Fancelli, 1986).

A massa média por unidade de grão ou semente é marcadamente afetada a partir do estádio 6 , principalmente pela disponibilidade de água.

Tal aumento ocorre, em grande parte, devido a translocação dos sintetizados presentes nas folhas e no colmo para a espiga e grãos em formação, cuja eficiência, além de ser importante para a produção, é extremamente dependente da disponibilidade de água.

Por outro lado, qualquer estresse entre os estádios 4 e 6 , reduz tanto a altura de planta como a área foliar. A redução do índice de área foliar (área foliar da cultura por unidade de área de solo explorado pela mesma) resulta na diminuição da taxa de interceptação de radiação luminosa com conseqüente perda de produção de carboidratos e rendimento (Fancelli, 1986).

Observações experimentais demonstraram que $50-60 \%$ dos carboidratos transportados para o grão de milho são oriundos das folhas localizadas na porção superior da planta, ao passo que aproximadamente $30 \%$ apresentam a contribuição das folhas situadas em seu terço médio, sendo o restante proveniente de suas folhas mais inferiores (Fancelli, 1986).

\subsection{Momento de aplicação dos herbicidas em pós-emergência}

A escolha do herbicida e de sua respectiva dose deverá se fundamentar em critérios rigorosos, objetivando a máxima eficiência e eficácia de controle, 
visto que tais produtos químicos podem elevar o custo de produção, provocar efeitos fitotóxicos na cultura, bem como se transformar em fonte de contaminação do ar, do solo e da água.

O controle químico de plantas daninhas na lavoura de milho pode ser representado pelo uso de herbicidas em pré-plantio (ou pré-semeadura), préemergência e pós-emergência.

Herbicidas de pré-plantio (PPI) devem ser aplicados antes da. semeadura da cultura e são apenas recomendados para sistemas convencionais de produção.

Os herbicidas de pré-emergência (PréE) devem ser aplicados após a semeadura da cultura e antes da emergência das espécies de plantas daninhas.

Herbicidas de pós-emergência (PósE) são aqueles ministrados após a emergência da cultura e das plantas daninhas a serem controladas. Por tanto, o desempenho satisfatório desse produto químico, quanto ao controle das espécies almejadas e menor efeito fitotóxico na cultura, é função da época de aplicação e do estádio da espécie comercial e das plantas daninhas (Fancelli \& Dourado-Neto, 2000).

Atualmente, a modalidade de pós-emergência é subdividida em (i) pósemergência precoce, quando as plantas daninhas de folhas largas apresentarem até duas folhas, as de folhas estreitas ainda não perfilharam e 0 milho apresentar 2 a 3 folhas abertas ( 3 a 7 dias após emergência); (ii) pósemergência inicial, quando as plantas daninhas de folhas largas apresentam duas a quatro folhas, as de folhas estreitas evidenciando o primeiro perfilho, e as plantas de milho com 4 a 5 folhas (15 dias após emergência aproximadamente), (iii) pós-emergência normal, quando as plantas daninhas de folhas largas apresentam de quatro a seis folhas, as de folhas estreitas de um a três perfilhos e o milho de 6 a 7 folhas (25 dias após emergência), e (iv) pós-emergência tardia ou jato dirigido quando as plantas de milho 
apresentarem de 7 a 10 folhas.

Segundo Velloso \& Souza (1993), é muito comum, na época da aplicação de herbicidas de pós-emergência seletivos, o atraso da aplicação em relação à idade das plantas daninhas, com conseqüente redução do nivel de controle, principalmente, quando se trata de aplicação de herbicidas à base de Atrazine em pós-emergência.

Segundo Silva \& Duarte (1997), muitas vezes, devido às dificuldades climáticas, o herbicida de pré-emergência não é aplicado e o Produtor Agrícola se vê a frente de uma lavoura onde a cultura de milho e as plantas daninhas já emergiram. Esse tipo de situação pode ocorrer pela falta de umidade no solo no momento da semeadura ou, como é mais comum, por falta de maquinário para semear e pulverizar ao mesmo tempo. Para controlar as plantas daninhas recém-emergidas, podem ser usados herbicidas de ação pós-emergente inicial, seletivos para a cultura de milho.

\subsection{Herbicidas de pós-emergência}

Diversos são os herbicidas e/ou misturas recomendados para o controle de plantas daninhas na cultura do milho, sendo a maioria aplicada em préemergência (Silva \& Melhorança, 1991).

Com o incremento da área de milho cultivada pelo sistema de plantio direto, surgiu a necessidade de se desenvolver novos herbicidas que fossem recomendados em pós-emergência (Pinto et al., 1993; Silva \& Altoé, 1993, Ferreira et al., 1995). O herbicida Nicosulfuron, lançado no mercado, mostrou alta seletividade para diferentes hibridos (Green \& Ulrich, 1993).

Segundo Toledo \& Begliomini (2000), há uma constatação do efeito mais eficaz dos herbicidas pós-emergentes em plantio direto pelo fato da cobertura morta com resíduos vegetais preservar a umidade do solo. Com isso, as plantas invasoras mantêm maior vigor vegetativo e säo mais bem controladas pelos herbicidas. Em função da diversidade de plantas daninhas encontradas 
no Brasil e da especificidade dos herbicidas aplicados em pós-emergência, as misturas de tanque se tornaram comuns.

Segundo Bastiani (1997), a mistura Nicosulfuron + Atrazine proporcionou controle eficiente das plantas daninhas sob diferentes umidades do solo, sendo seletivos para a cultura de milho, não provocando sinal de toxicidade no híbrido utilizado.

Vicente (1997), com o objetivo de avaliar a seletividade no milho OCEPAR 720 e o controle de plantas daninhas, instalou um experimento a campo no ano agrícola 1995/1996. Os tratamentos utilizados foram Nicosulfuron, Atrazine, Metolachlor + Atrazine e Nicosulfuron + Metolachlor + Atrazine aplicados em duas épocas. As plantas de milho apresentavam na primeira aplicação 3 a 4 folhas e na segunda 7 a 8 folhas. Nicosulfuron na dosagem de $120 \mathrm{~g} / \mathrm{ha}$ foi o tratamento que apresentou maior fitotoxicidade quando aplicado no milho com 7 a 8 folhas e os sintomas foram considerados leves.

Fancelli et al. (1998) observaram a manifestação de sensiveis reduçães de rendimento em lavouras de milho provocadas por grande parte dos herbicidas recomendados para a cultura, principalmente quando os mesmos foram aplicados após a emissão da sexta ou sétima folha do referido cereal. O rendimento não diferiu estatisticamente em função dos tratamentos, porém pôde-se observar a tendência de redução do rendimento com a aplicação tardia de Nicosulfuron na maior dose (1,3 L/ha). A análise dos resultados evidenciou as interferências do uso de determinados ingredientes ativos de herbicidas na cultura do milho, em função da dosagem empregada e do estádio fenológico da cultura. Nesse contexto, os tratamentos correspondentes ao uso de (i) Nicosulfuron (1,3 L/ha), (ii) Nicosulfuron (1,3 L/ha) + Atrazine (2 L/ha) e (iii) Nicosulfuron $(1,0 \mathrm{~L} / \mathrm{ha})+$ Atrazine $(2,0 \mathrm{~L} / \mathrm{ha})$, aplicados no estádio fenológico de 8 folhas, provocaram redução do número de fileiras por espiga e, conseqüentemente, redução do rendimento de grãos em relação ao tratamento 
testemunha. O emprego de Nicosulfuron na dosagem de 1,0 L/ha, mesmo no estádio de 8 folhas, bem como os demais tratamentos, não resultou em redução de rendimento, apesar da observação de sintomas de fitotoxicidade.

Segundo Silva \& Duarte (1997), a aplicação de herbicidas em pósemergência inicial é feita, normalmente, quando o milho apresenta de uma a quatro folhas e quando as plantas daninhas se encontram em tamanho menor do que $0,05 \mathrm{~m}(5 \mathrm{~cm})$ (latifoliadas) e antes do perfilhamento (gramíneas ou poáceas). Quando o milho estiver além desse estádio, podem surgir problemas de fitotoxicidade e a eficiência dos herbicidas pode ser menor em função do porte das plantas infestantes. Herbicidas como Cyanazine, Cyanazine + Simazine, 2,4-D amina e 2,4-D éster não são recomendados quando o milho ultrapassa o estádio de quatro folhas. Gramíneas (poáceas), como o capim marmelada (Brachiaria plantaginea (Link) Hitch.), são controladas nos estádios iniciais, mas se tornam resistentes a partir do perfilhamento e, nessa situação, somente o herbicida Nicosulfuron tem condições de controlá-las. Ainda, o uso de Nicosulfuron deve ser feito com cautela, seguindo-se rigorosamente as indicações do fabricante e seus distribuidores. Alguns híbridos de milho como o BR 3123, Cargill 969, Agroceres 200, Agromen 210, Germinal 600, Colorado 11. Pioneer 3230, Braskalb XL 320 e XL 370, têm-se mostrado pouco tolerantes ao herbicida acima citado, surgindo casos de injúrias iniciais.

O Nicosulfuron pertence ao grupo das sulfoniluréias sendo registrado no Brasil para a cultura do milho em pós-emergência, em área total, na dosagem de 1,25 a 1,50 L/ha ou 50 a $60 \mathrm{~g} / \mathrm{ha}$ do ingrediente ativo (i.a.) o qual controla gramíneas (poáceas), inclusive o capim-massambará (Sorghum halepense L.) e espécies latifoliadas (Almeida \& Rodrigues, 1995).

Santos \& Haden (1993), com o objetivo de verificar a seletividade do herbicida Nicosulfuron à cultura do milho, conduziram ensaios utilizando 82 híbridos nos estados do Paraná, São Paulo, Mato Grosso e Goiás. Foram utilizadas doses de 0,06 e 0,08 kg/ha do i.a., em pulverização de pós- 
emergência quando a cultura apresentava de 2 a 4 folhas, de 4 a 6 folhas, de 6 a 8 folhas e mais de 8 folhas. Foram feitas avaliações visuais de fitotoxicidade aos $7,14,21,42$ e 63 dias após aplicação do herbicida para cada estádio e dose estudados. Os sintomas visuais se caracterizaram por manchas estriadas de clorose (bem discretas) acompanhando as nervuras das folhas e ligeiro enrugamento na bordadura das mesmas. Para as doses aplicadas de 0,06 $\mathrm{kg} / \mathrm{ha}$ e $0,08 \mathrm{~kg} / \mathrm{ha}$, os danos foram de $10-20 \%$ e $10-25 \%$ na redução do crescimento, respectivamente. A maior freqüência de danos foi observada entre 4-8 folhas para a dose $0,06 \mathrm{~kg} / \mathrm{ha}$ e entre $2-8$ folhas para a dose $0,08 \mathrm{~kg} / \mathrm{ha}$. Os híbridos mais sensiveis, por freqüência de dano observado, foram XL-370, XL380 e ICl-8551 por porcentagem de dano ocasionado. Para a dose $0,06 \mathrm{~kg} / \mathrm{ha}$ não houve sintomas visuais de fitotoxicidade aos 63 dias após aplicação (DAA). Já para a dose $0,08 \mathrm{~kg} / \mathrm{ha}$ houve redução de crescimento variando de $5-10 \%$ em apenas 3 dos 82 materiais estudados.

Melhorança (1996) realizou um trabalho que teve como objetivo avaliar a eficiência do herbicida Nicosulfuron no controle de plantas daninhas, em aplicação aérea e terrestre em diferentes vazões, assim como observar o efeito no desenvolvimento vegetativo e rendimento da cultura do milho utilizando o híbrido Hatã 2000. O experimento foi conduzido a campo no município de Ponta Porã, MS. O herbicida foi aplicado em pós-emergência na dose de 60 g/ha do i.a. (1,5 L/ha do produto comercial - p.c.). As vazões foram 20,30 e 40 L/ha em aplicação aérea e 250 L/ha em aplicação terrestre. A dose de $60 \mathrm{~g} / \mathrm{ha}$ do i.a. de Nicosulfuron nas vazões utilizadas apresentou baixa fitotoxicidade, sendo seletiva para a cultura do milho.

Ferreira et al. (1995) avaliaram a eficiência do Nicosulfuron em duas formulações (SC $40 \mathrm{~g} / \mathrm{L}$ do i.a. e WDG $750 \mathrm{~g} / \mathrm{kg}$ do i.a.) no controle de plantas daninhas em lavoura de milho AG 102, comparada com dois herbicidas tradicionalmente recomendados. O Nicosulfuron, nas duas formulações, foi bem tolerado pela cultura do milho, na qual foram observadas apenas 
pequenas manchas cloróticas no limbo foliar sete dias após as aplicações, as quais desapareceram por completo aos quinze dias após seu aparecimento.

Silva et al. (1996), com o objetivo de avaliar o efeito da mistura de Atrazine + Nicosulfuron no controle pós-emergente de plantas daninhas na cultura de milho, instalaram um experimento de campo, na sede CNPMS/EMBRAPA, em Sete Lagoas, MG. Utilizou-se o BR 201 e os tratamentos foram Atrazine + Nicosulfuron a $(750+30) \mathrm{g} / \mathrm{ha},(875+35) \mathrm{g} / \mathrm{ha} \mathrm{e}$ $(1000+40) \mathrm{g} / \mathrm{ha}$; Nicosulfuron a 40,60 e $80 \mathrm{~g} / \mathrm{ha}$; Atrazine a 1000 e $2500 \mathrm{~g} / \mathrm{ha}$, e as testemunhas. Os herbicidas foram aplicados 17 dias após a emergência do milho ( 6 a 8 folhas e $0,25 \mathrm{~m}$ de altura). Verificou-se efeito fitotóxico dos tratamentos sobre a cultura, com índices médios inferiores a 2,5 (EWRC, 1964).

A mistura composta por Atrazine + óleo vegetal foi registrada no Brasil para a cultura do milho em pós-emergência na dosagem de 5,0 a 7,0 L/ha ou 3,5 a $4,9 \mathrm{~kg} / \mathrm{ha}$ do i.a. É utilizado para controle de capim-marmelada (Brachiaria plantaginea (Link) Hitch.) e folhas largas anuais, na fase de pós-emergência inicial (Almeida \& Rodrigues, 1995).

Borges et al. (1988) estudaram a mistura pronta de herbicidas contendo na sua composição Atrazine + óleo vegetal visando avaliar o desempenho biológico do produto e seletividade à cultura. A mistura foi aplicada nas dosagem de 5,0; 6,0 e 7,0 L/ha do produto formulado e a cultura apresentava 3 a 5 folhas. Observou-se alta seletividade da formulação às plantas de milho, não havendo, visualmente nenhuma influência no seu desenvolvimento, bem como no rendimento final.

Velloso \& Nardi (1993), com o objetivo de verificar o comportamento do herbicida Atrazine em formulação oleosa de $400 \mathrm{~g} / \mathrm{L}$ do i.a., no controle de plantas daninhas na cultura do milho utilizando doses de 5,$0 ; 6,0 ; 7,0$ e 8,0 L/ha do p.c., fizeram um ensaio na área experimental do CNPT/EMBRAPA. Foram realizadas duas avaliações da fitotoxicidade, aos 15 e aos 30 DAA. Os 
níveis de fitotoxicidade apresentados aos 15 DAA, foram leves nas quatro doses estudadas, sendo que, aos 30 DAA as plantas já não apresentavam sintomas de fitotoxicidade.

A mistura composta por Atrazine + Metolachlor foi registrada no Brasil para pré-emergência da cultura de milho e das plantas daninhas, com dosagem dependente da textura do solo. Sendo assim, para textura arenosa recomendase 5,0 a $6,0 \mathrm{~L} / \mathrm{ha}$ ou 2,5 a $3,0 \mathrm{~kg} / \mathrm{h} a$ do i.a.; para textura média recomenda-se 6,0 a $7,0 \mathrm{~L} / \mathrm{ha}$ ou 3,0 a $3,5 \mathrm{~kg} / \mathrm{ha}$ do i.a. e para textura argilosa recomenda-se 6,0 a $8,0 \mathrm{~L} / \mathrm{ha}$ ou 3,0 a $4,0 \mathrm{~kg} / \mathrm{ha}$ do i.a. Na mistura, o Metolachlor atua, essencialmente, sobre gramíneas (poáceas), e Atrazine sobre espécies de folha larga (Almeida \& Rodrigues, 1995).

Almeida \& Fornarelli (1988), com o objetivo de verificar a eficiência e a seletividade de herbicidas aplicados na pós-emergência das plantas daninhas na cultura do milho, conduziram um experimento na região de Londrina, utilizando o híbrido AG 401. Os tratamentos foram a mistura de Metolachlor e Atrazine $(1,8+1,2)$ e Metolachlor + Atrazine $(2,4+1,6) \mathrm{em} \mathrm{kg} / \mathrm{ha}$ de i.a. e os produtos foram aplicados quando a cultura apresentava 3 a 4 folhas. Quanto à fitotoxicidade, Metolachlor e Atrazine na maior dose apresentaram alguns sintomas aos 11 dias após tratamento (DAT), porém aos 30 DAT a cultura já estava totalmente recuperada.

Silva \& Baldez (1993), com a finalidade de testar o efeito em pósemergência da mistura de Atrazine com Metolachlor, realizaram um experimento no CNPMS/EMBRAPA utilizando o híbrido de milho BR-201. Foram utilizadas quatro dosagens da mistura aplicadas em dois estádios de desenvolvimento da cultura. Os tratamentos estudados foram Atrazine + Metolachlor nas doses de $(1,0+1,5),(1,2+1,8),(1,4+2,1)$ e $(2,4+3,6) \mathrm{kg} / \mathrm{ha}$ do i.a., quando a cultura apresentava duas e quatro folhas e, Atrazine formulado com óleo (suspensão concentrada em óleo com $400+300 \mathrm{~g} / \mathrm{L}$ ), a $2,4 \mathrm{~kg} / \mathrm{ha}$ do i.a., nos estádios de duas e de quatro folhas, como tratamento de 
comparação. A ação dos herbicidas sobre a cultura foi avaliada através da estimativa de sintomas visuais de injúria pela escala EWRC (1964) (1 a 9), variando de ausência a mortandade completa. A análise do efeito de Atrazine + Metolachlor sobre as plantas de milho, mostrou que o milho foi mais tolerante à mistura quando apresentou quatro folhas. Mostrou também uma tendência de incremento dos sintomas de injúria quando a dose foi aumentada. Não foram observadas diferenças significativas entre os tratamentos e a testemunha capinada, com relação ao número final de plantas, diâmetro do colmo e peso de grãos. Os autores concluíram que o produto pode ser usado no controle em pós-emergência inicial, recomendando-se sua aplicação em doses convencionais quando a cultura estiver com quatro folhas.

Watanabe et al. (1993) avaliaram a eficiência de controle e fitotoxicidade da mistura pronta Atrazine + Metolachlor a $(1,75+1,75) \mathrm{kg} / \mathrm{ha}$ do i.a., em pósemergência na cultura do milho comparando-a com testemunha capinada e o mesmo em pré-emergência. Observou-se fitotoxicidade nas avaliaçōes iniciais; porém, houve recuperação completa do milho. A adição de óleo mineral acentuou a fitotoxicidade, caracterizada por necrose das folhas.

A mistura composta por Atrazine + Simazine é utilizada em pré e pósemergência precoce para o controle de gramíneas (poáceas) e plantas daninhas de folha larga anuais, uma vez que o Simazine atua sobre ambas, e Atrazine essencialmente sobre as últimas. Porém, a dosagem depende da granulometria (ou textura, como normalmente é citado) do solo. Para textura arenosa, recomenda-se 3,5 a $5,0 \mathrm{~L} / \mathrm{ha}$ ou 1,75 a $2,5 \mathrm{~kg} / \mathrm{ha}$ do i.a., e para textura média a argilosa recomenda-se de 5,0 a $7,0 \mathrm{~L} / \mathrm{ha}$ ou 2,5 a $3,5 \mathrm{~kg} / \mathrm{ha}$ do i.a. (Almeida \& Rodrigues, 1995).

Almeida \& Oliveira (1982) estudaram o comportamento de diversos herbicidas aplicados em pós-emergência precoce (3-5 folhas do milho) e tardia (7-10 folhas) em seqüência ao pré-emergente Metolachlor e Atrazine. $\mathrm{Na}$ primeira modalidade, Cianazyne $(1,7$ a $2,2 \mathrm{~kg} / \mathrm{ha})$ provocou fitotoxicidade no 
milho, que se evidenciou por forte clorose foliar e redução de altura de plantas. Quando havia Atrazine na formulação, a sintomatologia foi acentuada, sendo mais drástica com a adição de surfactante $(0,1 \%)$. A fitotoxicidade de Simazine + Atrazine, na dosagem de $(1,6+1,6)$ e $(2,4+2,4) \mathrm{kg} / \mathrm{ha}$, foi menor, provocando paralização temporária de crescimento. A fitotoxicidade do Metolachlor + Atrazine, na dosagem de $(2,1+1,4) \mathrm{Kg} / \mathrm{ha}$, foi ligeiramente menor do que as duas formulações anteriores.

Almeida et al. (1988), com a finalidade de estudar a eficácia e a seletividade de herbicidas aplicados na pós-emergência inicial das plantas daninhas e da cultura do milho, conduziram um experimento na região de Londrina, utilizando o híbrido AG-301. A cultura apresentava de 7 a 10 folhas e os herbicidas testados, com suas respectivas dosagens, foram: mistura pronta de Atrazine + Simazine a $(1,5+1,5)$ e $(2,0+2,0) \mathrm{em} \mathrm{kg} / \mathrm{ha}$; mistura pronta de Atrazine + óleo vegetal $(2,0+1,5),(3,2+2,4),(4,0+3,0)$ e $(4,8+3,6) \mathrm{kg} / \mathrm{ha}$; mistura pronta de Metolachlor + Atrazine a $(1,8+1,2)$ e $(2,4+1,6) \mathrm{kg} / \mathrm{ha}$. As avaliações para fitotoxicidade foram feitas aos 17 e 44 DAT. Nenhum dos tratamentos apresentou sintomas de intoxicação e de redução da produção de grãos.

Duarte \& Palma (1995), avaliando o controle químico de Brachiaria decumbens em pós-emergência do milho (híbrido AG 1043), em experimento conduzido na área experimental da Universidade de Marilia, SP. Os tratamentos químicos foram as misturas prontas de Atrazine + Simazine $(1,75+$ $1,75) \mathrm{kg} / \mathrm{ha}$ do i.a. + óleo vegetal, Atrazine + óleo vegetal $(2,40+1,80) \mathrm{kg} / \mathrm{ha}$ do i.a., entre outros, e as aplicações foram feitas quando a cultura se encontrava com 4 a 8 folhas. Os tratamentos que continham óleo vegetal provocaram fitotoxicidade de 10 a $15 \%$, com redução da altura das plantas, porém essas recuperaram-se posteriormente. 


\section{MATERIAL E MÉTODOS}

\subsection{O local do experimento}

O experimento foi conduzido em Piracicaba-SP $\left(22^{\circ} 43^{\prime}\right.$ latitude Sul, $47^{\circ}$ 38 ' longitude Oeste, $580 \mathrm{~m}$ de altitude) na área experimental do Departamento de Produção Vegetal da Escola Superior de Agricultura "Luiz de Queiroz", Universidade de São Paulo, em solo classificado como Terra Roxa Estruturada (solo eutrófico, apresentando horizonte A moderado, e textura argilosa/muito argilosa).

\subsection{A cultura de milho}

O híbrido utilizado foi o Pioneer 3027 (hibrido triplo), ciclo precoce, com grão duro e cor alaranjada, apresentando necessidade calórica, para o florescimento, correspondente a 874 graus-dia $\left({ }^{\circ} \mathrm{C}\right.$.dia), sendo adequado à região de Piracicaba, SP, na época de semeadura estabelecida (Novembro). A massa de 1000 grãos é de, aproximadamente, $412 \mathrm{~g}$, a altura da planta varia de 2,45 a 2,65 metros, a altura de inserção da espiga oscila entre 1,20 a 1,35 metros e as folhas são semi-eretas. O híbrido Pioneer 3027 é recomendado para semeadura em áreas a serem tratadas com Nicosulfuron.

\subsection{Condução da cultura}

Em agosto, foi realizado o preparo do solo com grade intermediária, arado de disco e grade niveladora, com o objetivo de semear milheto + aveia para formação de palhada (semeadura realizada em 11 de agosto de 1998) e incorporado com grade niveladora. A adequada cobertura evitou o crescimento 
de plantas daninhas e problemas de erosão na área. A dessecação da palhada foi realizada em 22 de outubro de $1998 \mathrm{com}$ Glyphosate (3,5 L/ha) (Figura 5). Assim, o milho foi semeado em 10 de novembro de 1998, em sistema de plantio direto.

Realizou-se a semeadura utilizando uma semeadora Semeato PAR 2000 , de quatro linhas, regulada para a distribuição de 10 sementes $/ \mathrm{m}$, no espaçamento de 0,85 m (Figura 6).

$\mathrm{Na}$ adubação de semeadura foram utilizados $30 \mathrm{~kg}$ de nitrogênio $(\mathrm{N}), 80$ $\mathrm{kg}$ de fósforo $\left(\mathrm{P}_{2} \mathrm{O}_{5}\right)$ e $50 \mathrm{~kg}$ de potássio $\left(\mathrm{K}_{2} \mathrm{O}\right)$ por hectare, usando Sulfato de amônia como fonte de $\mathrm{N}$, Superfosfato simples como fonte de $\mathrm{P}_{2} \mathrm{O}_{5}$ e Cloreto de potássio como fonte de $\mathrm{K}_{2} \mathrm{O}$.

Após a emergência, foi realizado o desbaste ( 5 folhas) objetivando assegurar o estande de 5 plantas por metro linear, perfazendo uma população de 59.000 plantas por hectare na colheita.

Foram realizadas duas coberturas. A primeira quando a planta apresentou quatro folhas utilizando $60 \mathrm{~kg}$ de $\mathrm{N} / \mathrm{ha}$ e $30 \mathrm{~kg}$ de $\mathrm{K}_{2} \mathrm{O} / \mathrm{ha}$, utilizando como fonte Nitrato de amônio e Cloreto de potássio. A segunda cobertura foi realizada no estádio 2 ( 8 folhas) utilizando $30 \mathrm{~kg}$ de $\mathrm{N} / \mathrm{ha}$ usando como fonte Nitrato de amônio.

A cultura foi instalada sob irrigação por aspersão do tipo pivô central. Foi realizado acompanhamento diário da cultura com o objetivo de evitar danos decorrentes da lagarta do cartucho (Spodoptera frugiperda).

\subsection{Herbicidas, tratamentos e método de aplicação}

Os herbicidas (designação técnica) avaliados no presente experimento foram Atrazine + Metolachlor; Atrazine + Óleo; Atrazine + Simazine; e Nicosulfuron, devido representarem os principais produtos empregados na cultura do milho no Brasil. Esses herbicidas foram aplicados quando a cultura estava com 2 folhas (Figura 7), 4 folhas (Figura 8) e 8 folhas (Figura 9). 
Quadro 2. Descrição sucinta dos tratamentos.

\begin{tabular}{|c|c|c|c|}
\hline Tratamento & Descrição & $\mathrm{Nf}^{1}$ & $\mathrm{EF}^{2}$ \\
\hline 1 & Testemunha no limpo (sem herbicida) & - & - \\
\hline 2 & Atrazine + Metolachlor (7 L/ha) & 0 & - \\
\hline 3 & Atrazine + Metolachlor (5 L/ha) + Nicosulfuron $(0,5 \mathrm{~L} / \mathrm{ha})$ & 2 & $0-1$ \\
\hline 4 & Atrazine + óleo vegetal ( 6 Lha) & 2 & $0-1$ \\
\hline 5 & Atrazine + Simazine (5 L/ha) & 2 & $0-1$ \\
\hline 6 & Nicosulfuron $(1,0 \mathrm{~L} / \mathrm{ha})$ & 2 & $0-1$ \\
\hline 7 & Nicosulfuron $(0,5 \mathrm{~L} / \mathrm{ha})$ & 4 & 1 \\
\hline 8 & Nicosulfuron $(1,0 \mathrm{~L} / \mathrm{ha})$ & 4 & 1 \\
\hline 9 & Nicosulfuron (1,3 L/ha) & 4 & 1 \\
\hline 10 & Atrazine + óleo vegetal $(2 \mathrm{~L} / \mathrm{ha})+$ Nicosulfuron $(0,5 / \mathrm{ha})$ & 4 & 1 \\
\hline 11 & Atrazine + óleo vegetal (2 L/ha) + Nicosulfuron $(1,0 \mathrm{~L} / \mathrm{ha})$ & 4 & 1 \\
\hline 12 & Atrazine + óleo vegetal $(2 \mathrm{~L} / \mathrm{ha})+$ Nicosulfuron $(1,3 \mathrm{~L} / \mathrm{ha})$ & 4 & 1 \\
\hline 13 & Atrazine + óleo vegetal ( 6 L/ha) & 4 & 1 \\
\hline 14 & Atrazine + Simazine (5 L/ha) & 4 & $\overline{1}$ \\
\hline 15 & Nicosulfuron $(0,5 \mathrm{~L} / \mathrm{ha})$ & 8 & 2 \\
\hline 16 & Nicosulfuron $(1,0 \mid / / h a)$ & 8 & 2 \\
\hline 17 & Nicosulfuron (1,3 L/ha) & 8 & 2 \\
\hline 18 & Atrazine + óleo vegetal $(2 \mathrm{~L} / \mathrm{ha})+$ Nicosulfuron $(0,5 \mathrm{~L} / \mathrm{ha})$ & 8 & 2 \\
\hline 19 & Atrazine + óleo vegetal $(2 \mathrm{~L} / \mathrm{ha})+$ Nicosulfuron $(1,0 \mathrm{~L} / \mathrm{ha})$ & 8 & 2 \\
\hline 20 & Atrazine + óleo vegetal $(2 \mathrm{~L} / \mathrm{ha})+$ Nicosulfuron $(1,3 \mathrm{~L} / \mathrm{ha})$ & 8 & 2 \\
\hline 21 & Atrazine + óleo vegetal (6 L/ha) & 8 & 2 \\
\hline 22 & Atrazine + Simazine (5 L/ha) & 8 & 2 \\
\hline
\end{tabular}

1 Nf: número de folhas

2 EF: estádio fenológico (ver Quadro 1)

Os referidos produtos foram aplicados com auxilio de pulverizador terrestre tipo costal, com pressão constante de $3,0 \mathrm{Kgf} / \mathrm{cm}^{2}$, pressurizados a $\mathrm{CO}_{2}$, munido de barra com 4 bicos em leque espaçados a $0,50 \mathrm{~m}$, com ângulo de $80^{\circ}$, e vazão correspondente a $300 \mathrm{~L} / \mathrm{ha}$ de calda, assegurando distribuição 
uniforme.

Os tratamentos estudados estão apresentados no Quadro 2.

Cumpre ressaltar que foram realizadas capinas manuais, durante todo o ciclo da cultura objetivando a manutenção de todas as parcelas sempre no limpo, ou seja, livre da presença de plantas daninhas. Esses cuidados reduziram a interferência de outros fatores no rendimento, isolando de certa forma somente o efeito dos herbicidas.

Para evitar problemas de fitotoxicidade decorrente de outros fatores, foi observado um intervalo de 7 dias entre as adubações de cobertura e a aplicação de Nicosulfuron e para o controle da lagarta do cartucho não foram utilizados inseticidas organofosforados.

\subsection{Delineamento experimental}

O delineamento experimental adotado foi o de blocos ao acaso, apresentando 22 tratamentos e três repetições.

Assim, o experimento foi constituído por 66 parcelas experimentais, fundamentadas em 4 linhas espaçadas de 0,85 m, com 6,0 m de comprimento perfazendo área total de $20,4 \mathrm{~m}^{2}$ e área útil de $10,2 \mathrm{~m}^{2}$. As linhas externas foram consideradas como bordadura.

Aos resultados obtidos, foi aplicado o teste $F$ para verificar as diferenças entre os tratamentos, e as médias foram comparadas pelo teste de Tuckey com nivel de $5 \%$ de probabilidade.

\subsection{Características avaliadas}

\subsubsection{Caracteres agronômicos}

Foram avaliados os caracteres agronômicos avaliados foram: (i) fenologia, (ii) sintomas de fitotoxidez, (iii) área foliar, e (iv) altura de planta; Quadro 3, e os componentes da produção (i) prolificidade, (ii) comprimento da espiga, (iii) número de fileiras por espiga, (iv) número de grãos por fileira, (v) 
massa de 1000 grãos e (vi) rendimento de grãos (Quadro 4).

Quadro 3. Caracteres agronômicos avaliados no experimento.

\begin{tabular}{|c|c|}
\hline Componente & Caracteristica \\
\hline Fenologia & $\begin{array}{l}\text { A fenologia da cultura de milho foi avaliada diariamente } \\
\text { utilizando a escala proposta por Fancelli (1986) e Fancelli } \\
\text { \& Dourado-Neto (1997a), a qual subdivide o ciclo da } \\
\text { cultura em } 11 \text { diferentes etapas (estádios 0 a 10). Os } \\
\text { estádios de crescimento e desenvolvimento } \\
\text { anteriores ao aparecimento das espigas foram } \\
\text { identificados mediante avaliação do número de } \\
\text { folhas plenamente expandidas ou desdobradas. } \\
\text { Assim, a folha de milho foi considerada desdobrada } \\
\text { quando a mesma apresentou a linha de união } \\
\text { lâmina-bainha ("colar") facilmente visível. Para os } \\
\text { estádios posteriores à emissão da espiga, a } \\
\text { identificação foi efetuada com base no } \\
\text { desenvolvimento e consistência dos grãos (Fancelli } \\
\text { \& Dourado-Neto, 1997a). }\end{array}$ \\
\hline Sintomas de fitotoxidez & $\begin{array}{l}\text { Foram feitas avaliaçóes visuais de fitotoxicidade aos } \\
7,14 \text { e } 21 \text { dias após aplicação dos herbicidas em } \\
\text { cada parcela. Para tal, foi adotada a escala de notas } \\
\text { de } 1 \text { a } 9 \text { da EWRC (1964) (Quadro 5). }\end{array}$ \\
\hline Área foliar & $\begin{array}{l}\text { A determinação de área foliar da i-ésima folha (AFi, } \\
\mathrm{cm}^{2} \text { ) foi realizada no florescimento (Figura 10), } \\
\text { avaliando-se a planta inteira (amostragem } \\
\text { destrutiva), mediante a retirada e a respectiva } \\
\text { mensuração de cada folha no seu comprimento (Ci, } \\
\mathrm{cm} \text { ) e maior largura (Li, } \mathrm{cm} \text { ). Os dados obtidos foram } \\
\text { submetidos a seguinte a equação proposta por } \\
\text { Francis (1968): } \\
\mathrm{AFi}=0,75 . \mathrm{Ci} . \mathrm{Li}\end{array}$ \\
\hline Altura de planta & $\begin{array}{l}\text { Com auxilio de trena (escala graduada), foi medida a } \\
\text { altura de } 2 \text { plantas representativas de cada parcela } \\
\text { em pleno florescimento. }\end{array}$ \\
\hline $\begin{array}{l}\text { Altura de in } \\
\text { espiga }\end{array}$ & $\begin{array}{l}\text { elom auxilio de trena (escala graduada) foi } \\
\text { determinada a altura de inserção da espiga. }\end{array}$ \\
\hline
\end{tabular}




\subsubsection{Componentes da produção}

Quadro 4. Componentes da produção avaliados no experimento.

\begin{tabular}{|l|l|}
\hline \multicolumn{1}{|c|}{ Componente } & \multicolumn{1}{|c|}{ Características } \\
\hline Prolificidade & $\begin{array}{l}\text { O referido componente foi determinado pela simples } \\
\text { contagem do número de espigas viáveis por planta. }\end{array}$ \\
\hline Comprimento da espiga & $\begin{array}{l}\text { Foram selecionadas após a colheita, 20 espigas por } \\
\text { parcela, e medidas com o emprego de régua graduada. }\end{array}$ \\
\hline Número de fileiras por espiga & $\begin{array}{l}\text { Foi determinado, mediante simples contagem do número } \\
\text { de fileiras das espigas amostradas em cada parcela } \\
\text { utilizadas na determinação do comprimento. }\end{array}$ \\
\hline Número de grãos por fileira & $\begin{array}{l}\text { Foi determinado, mediante simples contagem do número } \\
\text { de grãos por fileira das espigas amostradas de cada } \\
\text { parcela e utilizadas na determinação do número de } \\
\text { fileiras. }\end{array}$ \\
\hline Massa de 1.000 grãos & $\begin{array}{l}\text { Todas as espigas colhidas foram debulhadas e do } \\
\text { volume obtido, foram retiradas } 8 \text { amostras de 100 grãos } \\
\text { ao acaso. Posteriormente, determino-se a umidade pelo } \\
\text { método padrão de estufa e estimou-se a massa de } \\
1.000 \text { grãos corrigida para 14\% de umidade. }\end{array}$ \\
\hline Rendimento de grãos & $\begin{array}{l}\text { Foi determinado pela debulha e pesagem dos grãos } \\
\text { oriundos das espigas colhidas da área útil da parcela, } \\
\text { devidamente corrigidos para 14\% de umidade. }\end{array}$ \\
\hline
\end{tabular}

Quadro 5. Escala European Weed Research Council (EWRC, 1964).

\begin{tabular}{|c|c|}
\hline Notas & Interpretação \\
\hline 1 & Nula (testemunha) \\
\hline 2 & Muito leve \\
\hline 3 & Leve \\
\hline 4 & Nenhum reflexo na reprodução \\
\hline 5 & Médio \\
\hline 6 & Quase médio \\
\hline 7 & Forte \\
\hline 8 & Muito forte \\
\hline 9 & Destruição total \\
\hline
\end{tabular}




\section{RESULTADOS E DISCUSSÃO}

\subsection{Caracteres agronômicos}

\subsubsection{Fenologia}

Quadro 6. Fenologia.

\begin{tabular}{|c|c|}
\hline Data & Evento \\
\hline 10 de novembro de 1998 & Semeadura \\
\hline 18 de novembro de 1998 & Emergência \\
\hline 24 de novembro de 1998 & 2 folhas \\
\hline 01 de dezembro de 1998 & 4 folhas \\
\hline 08 de dezembro de 1998 & 6 folhas \\
\hline 14 de dezembro de 1998 & 8 folhas \\
\hline 22 de dezembro de 1998 & 10 folhas \\
\hline 30 de dezembro de 1998 & 12 folhas \\
\hline 05 de janeiro de 1999 & 14 folhas \\
\hline 09 de janeiro de 1999 & Pendoamento \\
\hline 13 de janeiro de 1999 & Florescimento \\
\hline 28 de janeiro de 1999 & Grãos leitosos \\
\hline 11 de fevereiro de 1999 & Grãos pastosos \\
\hline 24 de fevereiro de 1999 & Grãos dentados \\
\hline
\end{tabular}

Conforme observado no Quadro 6, os estádios fenológicos da cultura aconteceram, com duração de cada um, conforme os intervalos teóricos 
descritos por Fancelli e Dourado-Neto (1997a) assim, a aplicação de herbicidas, em diferentes estádios fenológicos, não afetou a fenologia da cultura.

Segundo Fancelli \& Dourado-Neto (2000), a fenologia é definida como sendo o estudo dos eventos periódicos da vida da planta em função de sua reação às condições do ambiente. Assim, o uso da mesma, baseada nas mudanças morfológicos da planta e nos eventos fisiológicos que se sucedem no ciclo de vida do milho, oferece maior segurança e precisão nas ações de planejamento, de manejo e de pesquisa.

A duração dos estádios fenológicos (dias), principalmente, daqueles que definem o rendimento da cultura de milho (estádios fenológicos 1, 2, 3 e 6) não foram afetadas pelos herbicidas utilizados. A duração dessas etapas dependem, principalmente, do clima (temperatura), das características do híbrido e de algumas práticas agronômicas como irrigação e adubação.

\subsubsection{Sintomas de fitotoxidez}

Pode-se observar, no Quadro 7, que a aplicação de alguns herbicidas provocou efeitos muito leves de fitotoxicidade (nota 2). A mistura Atrazine + Metolachlor (5 L/ha) + Nicosulfuron $(0,5 \mathrm{~L} / \mathrm{ha})$ foi aplicada na cultura quando a apresentou 2 folhas, Nicosulfuron (1,3 L/ha) e Atrazine + Óleo Vegetal (2 L/ha) + Nicosulfuron (1,3 L/ha) foram aplicados na cultura quando a planta apresentou 4 e 8 folhas. Os sintomas visuais foram manchas estriadas de clorose (bem discretas) acompanhando as nervuras.

Para a mistura Atrazine + Metolachlor ( $\mathrm{L} / \mathrm{ha})+$ Nicosulfuron $(0,5 \mathrm{~L} / \mathrm{ha})$ aplicada na cultura quando a planta apresentou 2 folhas, os sintomas de fitotoxicidade foram observados aos 7 dias, sendo que, desapareceram naturalmente aos 14 dias. No caso de Nicosulfuron (1,3 L/ha) e Atrazine + Óleo Vegetal (2 L/ha) + Nicosulfuron (1,3 L/ha), aplicados na cultura com 4 e 8 folhas, os sintomas foram observados aos 3 dias após aplicação, sendo que, 
aos 7 dias tinham desaparecido naturalmente.

Quadro 7. Sintomas de fitotoxidez.

\begin{tabular}{|c|c|c|c|c|c|c|c|c|c|c|c|}
\hline \multirow[t]{2}{*}{$P^{1}$} & \multicolumn{3}{|c|}{$\mathrm{DAA}^{2}$} & \multirow[t]{2}{*}{$\mathbf{P}$} & \multicolumn{3}{|c|}{ DAA } & \multirow[t]{2}{*}{$\mathbf{P}$} & \multicolumn{3}{|c|}{ DAA } \\
\hline & 7 & 14 & 21 & & 7 & 14 & 21 & & 7 & 14 & 21 \\
\hline $1 \mathrm{~A}$ & & & & $1 \mathrm{~B}$ & & & & $1 \mathrm{C}$ & & & \\
\hline $2 A$ & 1 & 1 & 1 & $2 B$ & 1 & 1 & 1 & $2 \mathrm{C}$ & 1 & 1 & 1 \\
\hline $3 \mathrm{~A}$ & 2 & 1 & 1 & $3 B$ & 2 & 1 & 1 & $3 C$ & 2 & 1 & 1 \\
\hline $4 \mathrm{~A}$ & 1 & 1 & 1 & $4 B$ & 1 & 1 & 1 & $4 C$ & 1 & 1 & 1 \\
\hline $5 A$ & 1 & 1 & 1 & $5 B$ & 1 & 1 & 1 & $5 \mathrm{C}$ & 1 & 1 & 1 \\
\hline $6 \mathrm{~A}$ & 1 & 1 & 1 & $6 \mathrm{~B}$ & 1 & 1 & 1 & $6 C$ & 1 & 1 & 1 \\
\hline $7 \mathrm{~A}$ & 1 & 1 & 1 & $7 \mathrm{~B}$ & 1 & 1 & 1 & $7 \mathrm{C}$ & 1 & 1 & 1 \\
\hline $8 \mathrm{~A}$ & 1 & 1 & 1 & $8 B$ & 1 & 1 & 1 & $8 \mathrm{C}$ & 1 & 1 & 1 \\
\hline $9 A$ & $(2)^{3} 1$ & 1 & 1 & $9 \mathrm{~B}$ & (2) 1 & 1 & 1 & $9 \mathrm{C}$ & (2) 1 & 1 & 1 \\
\hline $10 \mathrm{~A}$ & 1 & 1 & 1 & $10 \mathrm{~B}$ & 1 & 1 & 1 & $10 \mathrm{C}$ & 1 & 1 & 1 \\
\hline $11 \mathrm{~A}$ & 1 & 1 & 1 & $11 \mathrm{~B}$ & 1 & 1 & 1 & $11 \mathrm{C}$ & 1 & 1 & 1 \\
\hline $12 \mathrm{~A}$ & (2) 1 & 1 & 1 & $12 \mathrm{~B}$ & (2)1 & 1 & 1 & $12 \mathrm{C}$ & (2)1 & 1 & 1 \\
\hline $13 \mathrm{~A}$ & 1 & 1 & 1 & $13 \mathrm{~B}$ & 1 & 1 & 1 & $13 \mathrm{C}$ & 1 & 1 & 1 \\
\hline $14 \mathrm{~A}$ & 1 & 1 & 1 & 14B & 1 & 1 & 1 & $14 \mathrm{C}$ & 1 & 1 & 1 \\
\hline $15 \mathrm{~A}$ & 1 & 1 & 1 & $15 \mathrm{~B}$ & 1 & 1 & 1 & $15 \mathrm{C}$ & 1 & 1 & 1 \\
\hline $16 \mathrm{~A}$ & 1 & 1 & 1 & $16 \mathrm{~B}$ & 1 & 1 & 1 & $16 \mathrm{C}$ & 1 & 1 & 1 \\
\hline $17 \mathrm{~A}$ & (2) 1 & 1 & 1 & $17 \mathrm{~B}$ & (2) 1 & 1 & 1 & $17 \mathrm{C}$ & (2) 1 & 1 & 1 \\
\hline $18 \mathrm{~A}$ & 1 & 1 & 1 & $18 \mathrm{~B}$ & 1 & 1 & 1 & $18 \mathrm{C}$ & 1 & 1 & 1 \\
\hline $19 \mathrm{~A}$ & 1 & 1 & 1 & $19 \mathrm{~B}$ & 1 & 1 & 1 & $19 \mathrm{C}$ & 1 & 1 & 1 \\
\hline $20 \mathrm{~A}$ & (2) 1 & 1 & 1 & $20 \mathrm{~B}$ & (2) 1 & 1 & 1 & $20 \mathrm{C}$ & (2) 1 & 1 & 1 \\
\hline $21 \mathrm{~A}$ & 1 & 1 & 1 & $21 \mathrm{~B}$ & 1 & 1 & 1 & $21 \mathrm{C}$ & 1 & 1 & 1 \\
\hline $22 \mathrm{~A}$ & 1 & 1 & 1 & $22 B$ & 1 & 1 & 1 & $22 \mathrm{C}$ & 1 & 1 & 1 \\
\hline
\end{tabular}

1 P: parcela

2 DAA: dias após a aplicação

3 sintomas observados aos 3 dias após a aplicação

\subsection{3 Área Foliar}

A superfície da folha fotossintéticamente ativa, em relação à unidade de superfície de solo explorada, é denominada de índice de área foliar (IAF). Tal parâmetro permite estimar o grau de desenvolvimento da planta e o potencial de interceptação de energia radiante (Fancelli \& Dourado-Neto, 1997b).

A redução do índice de área foliar ocasiona redução do metabolismo, 
com conseqüente perda de produção de carboidratos. Sendo assim, em termos absolutos, ter-se-á uma menor quantidade de fotoassimilados drenados para o colmo, principalmente, o que resultará num menor acúmulo de reserva a ser drenado para o grão (ou semente) a partir do estádio 6 .

Pode-se observar, na Tabela 1, que a aplicação de herbicidas nos diferentes estádios fenológicos não afetou estatisticamente (Tabela 3) a área foliar. Porém, foi observado que os tratamentos que continham Nicosulfuron, em diferentes dosagens ou misturas, provocaram redução dos valores médios, que oscilaram entre $2,6 \%$ a $9,0 \%$ quando comparados com a testemunha. 
Tabela 1. Características agronômicas.

\begin{tabular}{|c|c|c|c|c|}
\hline \multirow[t]{2}{*}{$T^{1}$} & \multirow[t]{2}{*}{ Descrição } & \multicolumn{3}{|c|}{ Médias* $^{*}$} \\
\hline & & $\mathrm{AF}^{2}$ & $\mathrm{AP}^{2}$ & $\mathrm{AE}^{2}$ \\
\hline 1 & Testemunha & $9472,61 a$ & $230,50 a$ & $130,17 a$ \\
\hline 2 & Atrazine + Metolachlor ( 7 L/ha) & $9740,59 a$ & $222,50 a$ & $132,83 a$ \\
\hline 3 & $\begin{array}{l}\text { Atrazine + Metolachlor (5L/ha) + } \\
\text { Nicosulfuron }(0,5 \mathrm{~L} / \mathrm{ha})\end{array}$ & $8966,30 a$ & $205,83 a$ & $136,00 \mathrm{a}$ \\
\hline 4 & Atrazine + Oleo Vegetal (6 L/ha) & $9224,75 a$ & $227,50 a$ & $140,67 a$ \\
\hline 5 & Atrazine+Simazine ( 5 L/ha) & $9835,03 a$ & $227,00 a$ & $138,67 a$ \\
\hline 6 & Nicosulfuron $(1,0 \mathrm{~L} / \mathrm{ha})$ & $8986,36 a$ & $220,33 a$ & $136,50 \mathrm{a}$ \\
\hline 7 & Nicosulfuron $(0,5 \mathrm{~L} / \mathrm{ha})$ & $9597,97 a$ & $225,67 a$ & $132,50 \mathrm{a}$ \\
\hline 8 & Nicosulfuron $(1,0 \mathrm{~L} / \mathrm{ha})$ & $9525,74 a$ & $225,50 a$ & $140,67 a$ \\
\hline 9 & Nicosulfuron $(1,3 \mathrm{~L} / \mathrm{ha})$ & $9006,58 a$ & $209,67 a$ & $134,83 a$ \\
\hline 10 & $\begin{array}{l}\text { Atrazine + Óleo Vegetal ( } 2 \text { Lha) }+ \\
\text { Nicosulfuron }(0,5 / \text { ha) }\end{array}$ & $9448,03 a$ & $223,83 a$ & $133,17 a$ \\
\hline 11 & $\begin{array}{l}\text { Atrazine + Óleo Vegetal ( } 2 \text { L/ha) + } \\
\text { Nicosulfuron }(1,0 \text { L/ha) }\end{array}$ & $9491,91 a$ & $216,50 a$ & $129,83 a$ \\
\hline 12 & $\begin{array}{l}\text { Atrazine + Oleo Vegetal ( } 2 \text { L/ha)+ } \\
\text { Nicosulfuron }(1,3 \text { L/ha) }\end{array}$ & $9204,46 a$ & $223,00 a$ & $129,33 a$ \\
\hline 13 & Atrazine + Óleo Vegetal ( 6 L/ha) & $9509,18 a$ & $213,67 a$ & $135,33 a$ \\
\hline 14 & Atrazine + Simazine ( 5 L/ha) & $9475,90 a$ & $226,67 a$ & $136,00 \mathrm{a}$ \\
\hline 15 & Nicosulfuron $(0,5 \mathrm{~L} / \mathrm{ha})$ & $9589,43 a$ & $224,33 a$ & $131,83 a$ \\
\hline 16 & Nicosulfuron $(1,0 \mathrm{~L} / \mathrm{ha})$ & $9080,27 a$ & $229,17 a$ & $137,50 \mathrm{a}$ \\
\hline 17 & Nicosulfuron $(1,3$ L/ha) & $8643,08 a$ & $221,50 \mathrm{a}$ & $129,83 a$ \\
\hline 18 & $\begin{array}{l}\text { Atrazine + Óleo Vegetal ( } 2 \text { L/ha })+ \\
\text { Nicosulfuron }(0,5 \mathrm{~L} / \mathrm{ha})\end{array}$ & $9128,22 a$ & $227,83 a$ & $133,83 a$ \\
\hline 19 & $\begin{array}{l}\text { Atrazine + Oleo Vegetal ( } 2 \text { Lha })+ \\
\text { Nicosulfuron }(1,0 \text { L/ha) }\end{array}$ & $8692,09 a$ & $220,67 a$ & $129,50 a$ \\
\hline 20 & $\begin{array}{l}\text { Atrazine + Oleo Vegetal ( } 2 \mathrm{~L} / \mathrm{ha})+ \\
\text { Nicosulfuron }(1,3 \mathrm{~L} / \mathrm{ha})\end{array}$ & $9025,26 a$ & $225,33 a$ & $134,17 a$ \\
\hline 21 & Atrazine + Óleo Vegetal (6 L/ha) & $9294,44 a$ & $218,33 a$ & $131,83 a$ \\
\hline 22 & Atrazine + Simazine $(5 \mathrm{~L} / \mathrm{ha})$ & $9296,83 a$ & $211,33 a$ & $125,17 a$ \\
\hline Coeficier & e de Variação $(\mathrm{CV} ; \%)$ & 5,96 & 3,56 & 6,41 \\
\hline
\end{tabular}

\subsubsection{Altura de planta}

Pode-se observar, na Tabela 1, que a aplicação de herbicidas em diferentes estágios fenológicos não afetou estatisticamente (Tabela 4) a altura da planta. A média da testemunha foi maior que os outros tratamentos nos diferentes momentos de aplicação. As aplicações de Atrazine + Metolachlor (5 L/ha) + Nicosulfuron (0,5 L/ha) com plantas apresentando duas folhas e Nicosulfuron (1,3 L/ha) com plantas apresentando 4 folhas, provocaram redução da altura das plantas de 11 a $9 \%$, respectivamente. As dosagens de 
Nicosulfuron, aplicadas em forma isolada ou em mistura, provocaram uma redução de altura de 2 a $6 \%$ (tratamentos 7 a 11).

\subsubsection{Altura de inserção da espiga}

Pode-se observar, na Tabela 1, que a aplicação de herbicidas em diferentes estágios fenológicos (em pós-emergência) não afetou estatisticamente (Tabela 5) a altura de inserção da espiga nas plantas. A altura de inserção da espiga é importante fator no planejamento da colheita mecanizada (Fancelli \& Dourado-Neto, 2000; e Sales, 1991).

\subsection{Componentes da produção}

\subsubsection{População}

Foi realizado o desbaste para uniformização da população para obtenção 59.000 plantas por hectare na colheita. Observou-se que a população pretendida foi atingida. Sendo assim, a aplicação de herbicidas não afetou a esse componente (população).

\subsubsection{Prolificidade}

A Tabela 2 mostra que a prolificidade foi de uma espiga por planta.

\subsubsection{Comprimento da espiga}

Pode-se observar, na Tabela 2, que a aplicação de herbicidas em diferentes estágios fenológicos não afetou estatisticamente (Tabela 6) o comprimento da espiga nos diferentes tratamentos. Os herbicidas com Nicosulfuron na máxima dose (1,3 L/ha), em forma isolada e em mistura, aplicados quando a planta apresentou 4 a 8 folhas, Atrazine + Óleo com 8 folhas, e Nicosulfuron na dose de 1 L/ha provocaram as menores médias, variando entre 2,2 a $3,5 \%$, respectivamente, quando comparados com a testemunha. 


\subsubsection{Número de fileiras por espiga}

Pode-se observar, na Tabela 2, que a aplicação de herbicidas nos diferentes estádios fenológicos afetou significativamente (Tabela 7) o número de fileiras por espiga (Figura 1). Os tratamentos 1 (testemunha) e 14 (Atrazine + Simazine) foram diferentes dos demais tratamentos. 0 tratamento 17 apresentou menor média. Pode-se observar que os herbicidas com Nicosulfuron nas diferentes doses, aplicados isoladamente e em mistura, provocaram redução no número de fileiras quando aplicados na cultura apresentando 8 folhas, principalmente, na maior dose.

Segundo Andrade et al. (1996), quando as plantas apresentam de quatro a seis folhas plenamente expandidas, o meristema apical finaliza a diferenciação de folhas e começa a diferenciar os primórdios da panícula. Nesse momento do desenvolvimento é determinado o número de folhas e, sendo assim, o índice de área foliar que pode ser atingido pela planta. Após o início da diferenciação da panícula, quando a planta se encontra com sete a nove folhas plenamente expandidas, começa o processo de diferenciação floral da gema que dará origem à espiga. Após a diferenciação, rapidamente, é determinado o número de fileiras por espiga e o número de grãos por fileira.

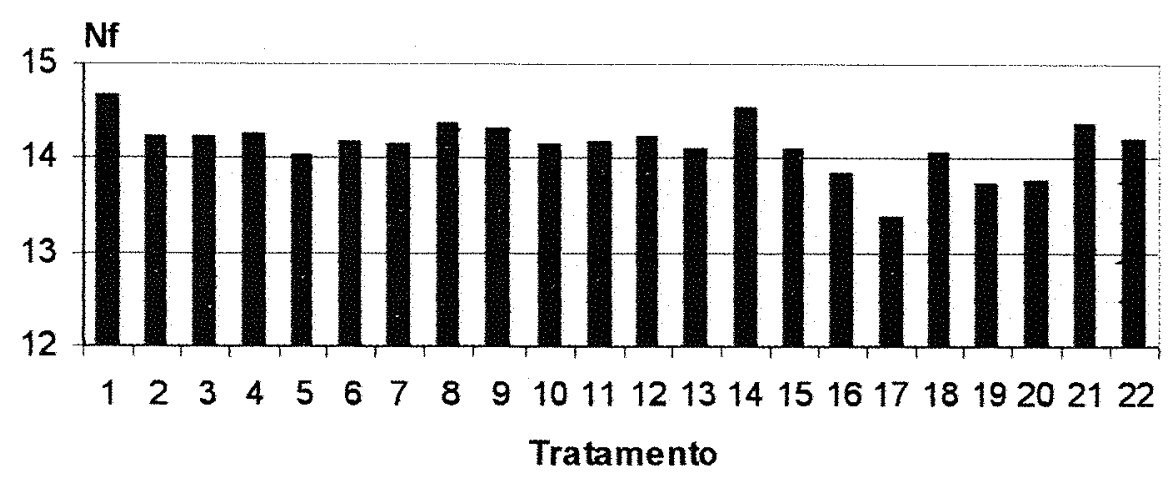

Figura 1. Variação do número de fileiras por espiga (Nf) referente aos diferentes tratamentos. 


\subsubsection{Número de grãos por fileira}

Pode-se observar, na Tabela 2, que a aplicação de herbicidas em diferentes estágios fenológicos provocou diferença estatística significativa (Tabela 8) entre os tratamentos. O tratamento testemunha foi estatisticamente superior a todos os demais tratamentos (Figura 2). $O$ tratamento Nicosulfuron + Atrazine, na dose máxima, proporcionou a menor média. As aplicações quando a planta apresentou 8 folhas nos diferentes tratamentos, e a aplicação de Nicosulfuron em plantas com 2 e 4 folhas apresentaram as menores médias provocando redução de 4,5 a 9,6\%, quando comparados com a testemunha. 
Tabela 2. Componentes de produção.

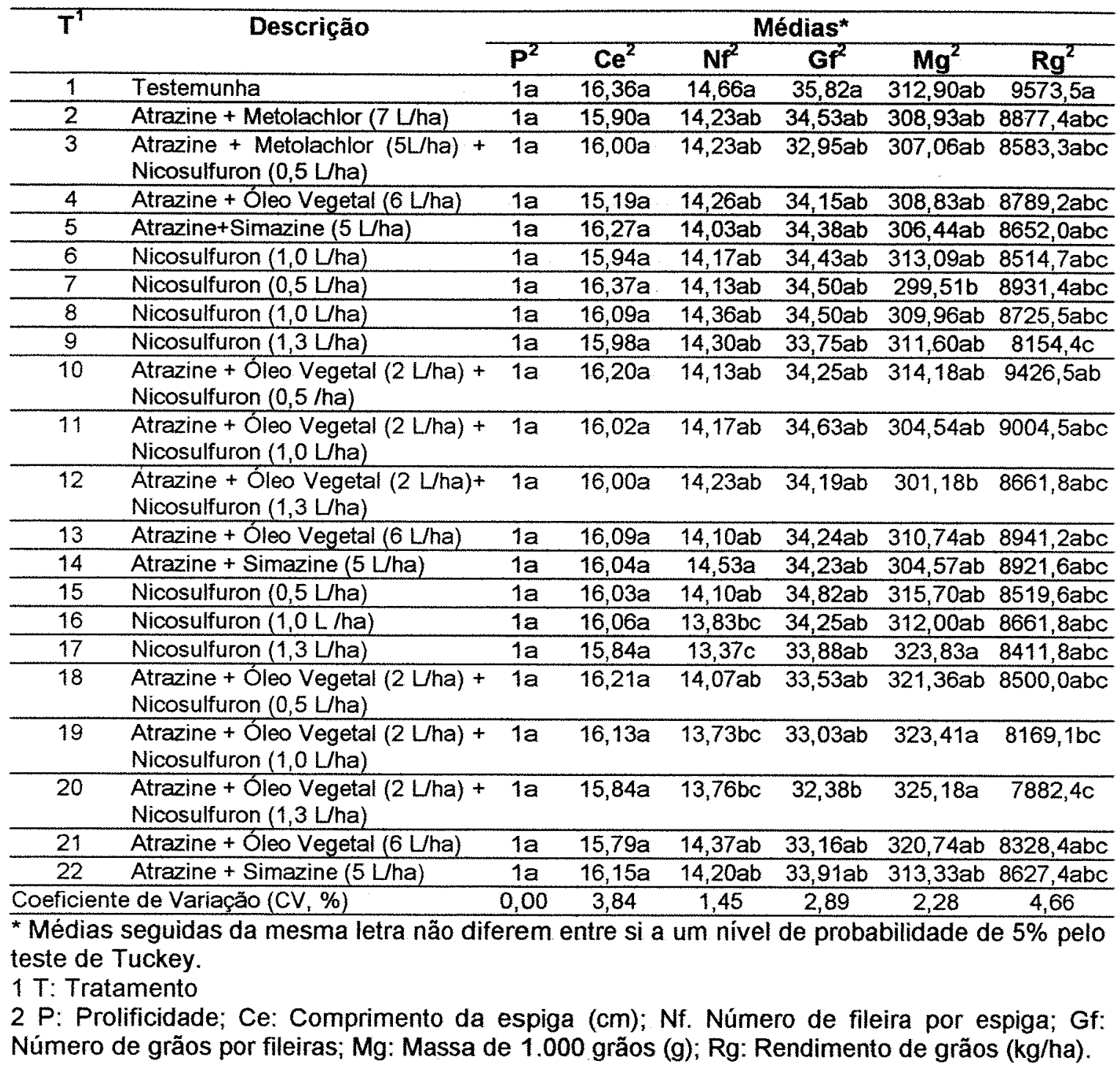




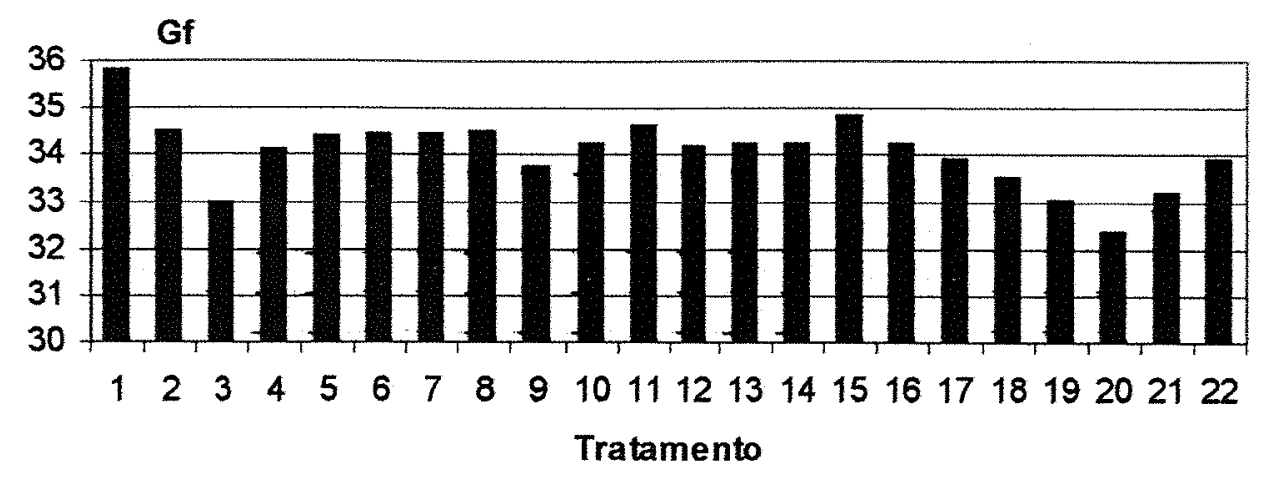

Figura 2. Variação do número de grãos por fileira (Gf) referente aos diferentes tratamentos.

\subsubsection{Massa de 1000 grãos}

Pode-se observar, na Tabela 2, que a aplicação de herbicidas em diferentes estágios fenológicos provocou diferença estatística significativa (Tabela 9) entre os tratamentos. Os tratamentos 17,19 e 20 foram estatisticamente superiores aos outros tratamentos (os grãos mais densos). Os tratamentos 7 e 12 apresentaram as menores médias. Pode-se observar que os tratamentos com Nicosulfuron nas maiores dosagens (tratamentos 17, 19 e 20), quando aplicados em plantas com 8 folhas, provocaram aumento na massa de 1000 grãos; porém, esse fato pode ser justificado devido ao menor número de fileiras por espiga e ao menor número de grãos por fileira (Figura 3). Quando comparados com a testemunha, os tratamentos 17,19 e 20 apresentam 3,3 a $3,9 \%$ de acréscimo na massa de 1000 grãos, e os tratamentos 7 e 12 redução de 3,7 e 4,3\%, respectivamente.

Andrade et al. (1996) evidenciaram que a diminuição de 70 a $80 \%$ do número de grãos promoveu apenas $30 \%$ de aumento de massa nos grãos remanescentes, demonstrando que o milho não tem a capacidade de compensar a perda de grãos pelo incremento em massa. 


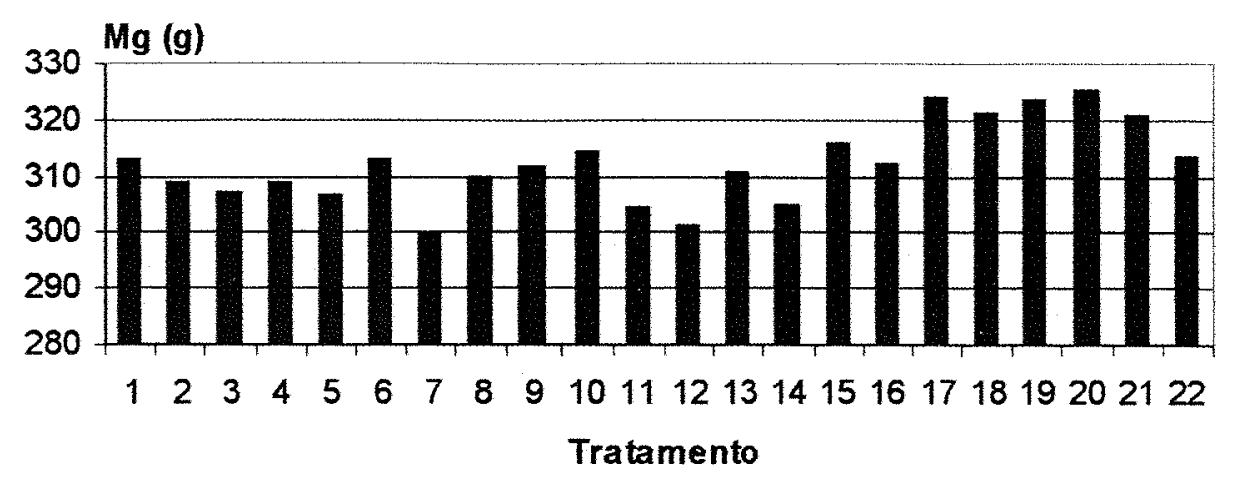

Figura 3. Variação da massa $(\mathrm{Mg}, \mathrm{g})$ de 1000 grãos referente aos diferentes tratamentos.

\subsubsection{Rendimento de grãos}

Pode-se observar, na Tabela 2, que os herbicidas aplicados nos diferentes estádios fenológicos provocaram diferença estatística (Tabela 10) entre os tratamentos. O tratamento 1 (Testemunha) foi estatisticamente superior aos outros tratamentos. Os tratamentos 9 e 20 foram os que apresentaram os menores valores. Pode-se observar que os herbicidas que apresentaram Nicosulfuron na maior dosagem (1,3 L/ha), quando aplicados em plantas com 4 e 8 folhas, e Nicosulfuron (1,0 L/ha) em plantas com 2 folhas provocaram redução do rendimento de grãos (Figura 4). Essa redução foi maior quando os herbicidas foram aplicados por ocasião de 8 folhas, principalmente, por provocarem redução do número de fileiras por espiga e número de grãos por fileira. É importante ressaltar que a massa de 1000 grãos foi maior nos tratamentos cujo controle químico foi realizado em plantas com 8 folhas, porém não foi o suficiente para compensar o menor número de grãos por espiga. A redução de rendimento de grãos dos tratamentos que apresentaram as menores médias em relação à testemunha foi entre 11,2 a $17,6 \%$, 
aproximadamente.

Segundo Fancelli \& Dourado-Neto (1997b) e Andrade et al. (1996), o número de grãos por unidade de área constitui um dos mais importantes componentes determinantes do rendimento, o qual é influenciado por eventos ocorridos entre a emissão da $4^{a}$ e $10^{a}$ folha, além daqueles evidenciados no florescimento (fecundação).

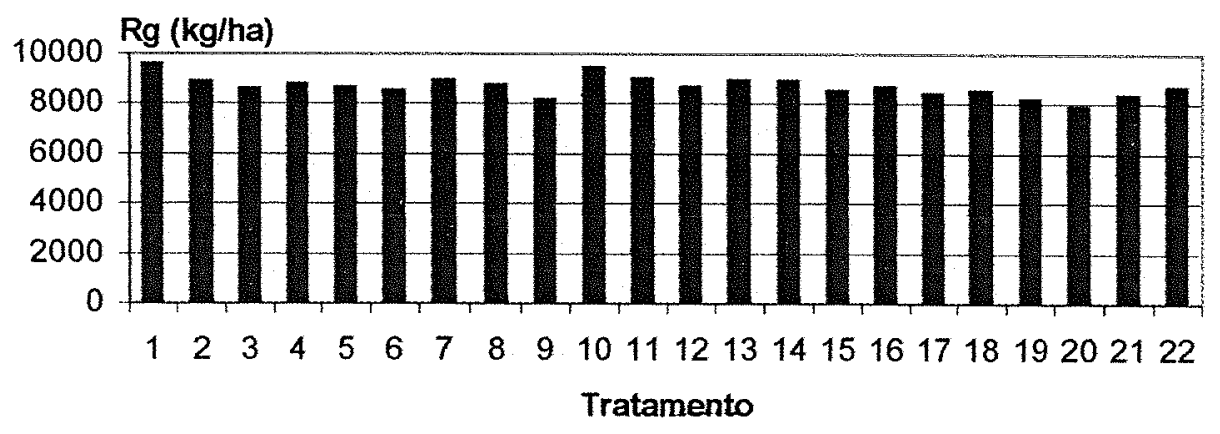

Figura 4. Variação do rendimento médio de grãos $(\mathrm{Rg}, \mathrm{kg} / \mathrm{ha})$ referente aos diferentes tratamentos.

\subsection{Considerações finais}

Em função dos resultados, algumas considerações são pertinentes:

(i) a aplicação de herbicidas na cultura de milho apresentando 8 folhas pode provocar redução do rendimento, não sendo aconselhável a aplicação desses produtos após 4 folhas (estádio 1) para evitar risco de fitotoxicidade;

(ii) a partir da quinta folha, a presença de plantas daninhas na lavoura de milho poderá acarretar perdas significativas no rendimento em função de competição por fatores de produção, bem como por eventuais efeitos decorrentes da liberação de aleloquímicos, no meio, por algumas espécies vegetais. O nível de redução no rendimento da cultura é função de seu estádio de desenvolvimento, das espécies daninhas presentes na área, da dosagem e do tipo de herbicida aplicado. 


\section{CONCLUSÕES}

Em função dos resultados obtidos e do que foi discutido, pode-se concluir que, para a cultura de milho, em sistema de plantio direto:

(i) a duração dos estádios fenológicos não é afetada pelos herbicidas utilizados;

(ii) os danos dependem dos ingredientes ativos, da dosagem e do estádio fenológico da cultura no momento da aplicação do herbicida;

(iii) os herbicidas não comprometem a área foliar, porém reduzem o rendimento de grãos, afetando os componentes de produção (a) número de fileiras por espiga, (b) número de grãos por fileira, e (c) massa de 1000 grãos;

(iv) o herbicida Nicosulfuron, quando aplicado em dose de 1,3 L/ha, por ocasião da $8^{\mathrm{a}}$ folha, reduz o rendimento da cultura;

(v) o manejo químico de plantas daninhas deve ser efetuado até 4 folhas (estádio 1) para evitar danos por fitotoxicidade provocada pelos herbicidas. 


\section{ANEXO: Análise estatística}

Tabela 3. Análise de variância referente à área foliar $\left(\mathrm{cm}^{2}\right)$.

\begin{tabular}{lccccc}
\hline Causas de variação & G.L. & S.Q. & Q.M. & Valor F & n.s. $^{{ }^{\prime}}$ \\
\hline Tratamento & 21 & 6378295,50 & 303728,36 & 1,02 & 0,4570 \\
\hline Resíduo & 44 & 13047449,12 & 296532,93 & & \\
\hline Total & 65 & 19425744,62 & & & \\
\hline
\end{tabular}

1 n.s.: nivel de significância

Tabela 4. Análise de variância referente à Altura de planta $(\mathrm{cm})$.

\begin{tabular}{lccccc}
\hline \multicolumn{1}{c}{ Causas de variação } & G.L. & S.Q. & Q.M. & Valor F & n.s. $^{{ }^{\prime}}$ \\
\hline Tratamento & 21 & 2772,83 & 132,04 & 1,65 & 0,081 \\
\hline Resíduo & 44 & 3528,83 & 80,20 & & \\
\hline Total & 65 & 6301,66 & & & \\
\hline
\end{tabular}

1 n.s.: nível de significância

Tabela 5. Análise de variância referente à altura de Inserção da espiga (cm).

\begin{tabular}{lccccc}
\hline \multicolumn{1}{c}{ Causas de variação } & G.L. & S.Q. & Q.M. & Valor F & n.s. $^{{ }^{1}}$ \\
\hline Tratamento & 21 & 960,21 & 45,72 & 0,62 & 0,8799 \\
\hline Resíduo & 44 & 3237,16 & 73,57 & & \\
\hline Total & 65 & 4197,38 & & & \\
\hline
\end{tabular}

1 n.s.: nível de significância 
Tabela 6. Análise de variância referente ao comprimento de espiga $(\mathrm{cm})$

\begin{tabular}{lccccc}
\hline \multicolumn{1}{c}{ Causas de variação } & G.L. & S.Q. & Q.M. & Valor F & n.s. $^{{ }^{\prime}}$ \\
\hline Tratamento & 21 & 1,58 & 0,075 & 0,20 & 0,9999 \\
\hline Resíduo & 44 & 16,72 & 0,38 & & \\
\hline Total & 65 & 18,30 & & & \\
\hline
\end{tabular}

1 n.s.: nível de significância

Tabela 7. Análise de variância referente ao número de fileiras por espiga.

\begin{tabular}{lccccc}
\hline Causas de variação & G.L. & S.Q. & Q.M. & Valor F & Prob > F \\
\hline Tratamento & 21 & 4,87 & 0,23 & 5,49 & 0,0001 \\
\hline Residuo & 44 & 1,86 & 0,04 & & \\
\hline Total & 65 & 6,73 & & & \\
\hline
\end{tabular}

1 n.s.: nivel de significância

Tabela 8. Análise de variância referente ao número de grãos por fileira.

\begin{tabular}{lccccc}
\hline Causas de variação & G.L. & S.Q. & Q.M. & Valor F & n.s. $^{{ }^{\prime}}$ \\
\hline Tratamento & 21 & 33,82 & 1,61 & 1,67 & 0,0745 \\
\hline Resíduo & 44 & 42,32 & 0,96 & & \\
\hline Total & 65 & 76,14 & & & \\
\hline
\end{tabular}

1 n.s.: nível de significância

Tabela 9. Análise de variância referente à massa de 1000 sementes (g).

\begin{tabular}{lccccc}
\hline \multicolumn{1}{c}{ Causas de variação } & G.L. & S.Q. & Q.M. & Valor F & n.s. $^{1}$ \\
\hline Tratamento & 21 & 3282,48 & 156,31 & 3,08 & 0,0008 \\
\hline Resíduo & 44 & 2230,18 & 50,68 & & \\
\hline Total & 65 & 5512,66 & & & \\
\hline
\end{tabular}

1 n.s.: nivel de significância 
Tabela 10. Análise de variância referente ao rendimento de grãos (kg/ha).

\begin{tabular}{lccccc}
\hline Causas de variação & G.L. & S.Q. & Q.M. & Valor F & n.s. $^{1}$ \\
\hline Tratamento & 21 & 9514457,25 & 453069,39 & 2,77 & 0,0022 \\
\hline Resíduo & 44 & 7195594,04 & 163536,22 & & \\
\hline Total & 65 & 16710051,29 & & & \\
\hline
\end{tabular}

1 n.s.: nível de significância 


\section{REFERÊNCIAS BIBLIOGRÁFICAS}

ALMEIDA, F.S.; OLIVEIRA, V.F. Estudo de tratamentos pós-emergentes para controle de infestações tardias na cultura do milho. In: CONGRESSO NACIONAL DE MILHO E SORGO, 14., Florianópolis, 1982. Resumos. Florianópolis: EMPASC, 1982. p.108.

ALMEIDA, F.S.; RODRIGUES, B.N. Guia de herbicidas. 3. ed., Londrina: Autores, 1995. 675p.

ALMEIDA, J.C.V.; FORNARELLI, D.A.; CHEHATA, A.N. Eficiência e seletividade de herbicidas aplicados em pós-emergência inicial das plantas daninhas e da cultura do milho. In: CONGRESSO BRASILEIRO DE HERBICIDAS E PLANTA DANINHAS, 19., Piracicaba, 1988. Resumos. Piracicaba: Legis Summa, 1988. p.255-256.

ALMEIDA, S.C.V.; FORNARELLI, D.A. Eficiência e seletividade de herbicidas aplicados em pós-emergência na cultura do milho. In: CONGRESSO NACIONAL DE MILHO E SORGO, 17., Piracicaba, 1988. Resumos. Piracicaba: FEALQ, 1988. p.35-36.

ANDRADE, F.; CIRILO, A.; UHART, S.; OTEGUI, M. Ecofisiologia del cultivo de maíz. Balcarce: La Barrosa, 1996. 292p. 
BASTIANI, M.L.R. Atividade dos herbicidas nicosulfuron e atrazine, em condições de casa-de-vegetação e de campo. Viçosa, 1997. 59p. Dissertação - (Mestrado). Universidade Federal de Viçosa.

BORGES E.; UEDA, A.; ARAMAKI, P. Atrazine + óleo no controle em pósemergência das plantas daninhas na cultura do milho. In: CONGRESSO BRASILEIRO DE HERBICIDAS E PLANTA DANINHAS, 19. Piracicaba, 1988. Resumos. Piracicaba: Legis Summa, 1988. p.264-265.

DUARTE, F., PALMA, V. de. Controle de Brachiaria decumbens em pósemergência na cultura do milho. In: CONGRESSO BRASILEIRO DA CIÊNCIA DAS PLANTAS DANINHAS, 19., Florianópolis, 1995. Resumos. Florianópolis: SBCPD, 1995. p.152-154.

DOURADO-NETO, D. FANCELLI, A.L. Milho: Equações gerais para manejo da cultura de milho. In: FANCELLI, A.L., DOURADO-NETO, D. (Coord.) Tecnologia da produção de milho. Piracicaba: Publique, 1997. p.171-174.

EUROPEAN WEED RESEARCH COUNCIL. Comittee of Methods in Weed Research. Report of the $3^{\mathrm{a}}$ and $4^{\mathrm{a}}$ meetings of EWRC. Oxford, 1964. v.4, p.88,

FANCELLI, A.L. Plantas alimentícias: guia para aula, estudos e discussão. Piracicaba: ESALQ, Departamento de Agricultura, 1986. 131p.

FANCELLI, A.L.; DOURADO-NETO, D. Fenologia do milho. In: FANCELLI, A.L.; DOURADO-NETO, D. (Coord.) Tecnologia da produção de milho. Piracicaba: Publique, 1997a. p.131-140. 
FANCELLI, A.L.; DOURADO-NETO, D. Milho: Ecofisiologia e Rendimento. In: FANCELLI, A.L., DOURADO-NETO, D. (Coord.) Tecnologia da produção de milho. Piracicaba: Publique, 1997b. p.157-170.

FANCELLI, A.L.; DOURADO-NETO, D. Produção de milho. Guaiba: Agropecuária, 2000. 360 p.

FANCELLI, A.L.; OVEJERO, R.F.; DOURADO-NETO, D.; VOCURCA, $H$. Influência do uso de herbicidas no rendimento e nos componentes de produção de milho. In: CONGRESSO NACIONAL DE MILHO E SORGO, 22. Recife, 1998. Resumos. Recife: 1998. p.245.

FERREIRA, F.A.; SILVA, A.A. D.A.; FERREIRA, L.R. Efeitos do Nicosulfuron, em duas formulações, sobre o controle de plantas daninhas na cultura do milho. In: CONGRESSO BRASILEIRO DA CIENCIA DAS PLANTAS DANINHAS, 19, Florianópolis, 1995. Resumos. Florianópolis, SBCPD, 1995. p.164-165.

FNP CONSULTORIA \& COMÉRCIO, AGRIANUAL 2000: anuário da agricultura brasileira. São Paulo, 2000. 435p.

FRANCIS, C.A.; RUTGER, J.N.; PALMER, A.F.E. A rapid method for plant leaf area estimation in maize. Crop Science, v.9, p.537-539, 1969.

GREEN, J.M.; ULRICH, J.F. Response to corn (Zea mays L.) inbrids and hibrids to sulfonilureas herbicides. Weed Science, v.41, 1993. p.508-516.

MELHORANÇA, A.L. Controle de plantas daninhas com nicosulfuron aplicado via aérea e terrestre na cultura do milho. In: CONGRESSO NACIONAL DE 
MILHO E SORGO, 20; Londrina, 1996. Resumos. Londrina: IAPAR, 1996. p.179.

PINTO, J.J.O.; ALMEIDA, R.; HASSMANN, J.S. Avaliação do herbicida Nicosulfuron aplicado em pós-emergência na cultura de milho. In: CONGRESSO BRASILEIRO DE HERBICIDAS E PLANTAS DANINHAS, 19. Londrina, 1993, Resumos. Londrina: IAPAR, 1993. p.152.

SALES, J.L. Determinação dos períodos de interferência e integração de práticas culturais com herbicidas no controle de plantas daninhas na cultura de milho (Zea mays L.). Piracicaba, 1991. Tese (Doutorado). Escola Superior de Agricultura "Luiz de Queiroz", Universidade de São Paulo. $151 \mathrm{p}$.

SANTOS J.M., HADEN, E. Avaliação da seletividade a diferentes doses e épocas de aplicação do herbicida nicosulfuron em diferentes cultivares de milho. In: CONGRESSO BRASILEIRO DE HERBICIDAS E PLANTA DANINHAS, 19., Londrina, 1993. Resumos. Londrina: SBHED, 1993. p.166-167.

SILVA, A.A. da; ALTOÉ, I.F. Efeitos do nicosulfuron sobre a cultura do milho e no controle de plantas daninhas. In: CONGRESSO BRASILEIRO DE HERBICIDAS E PLANTAS DANINHAS, 19. Londrina, 1993. Resumos. Londrina: IAPAR, 1993. p.153.

SILVA, A.A. da; MELHORANÇA, A.L. Controle de plantas daninhas na cultura do milho. In: Empresa Brasileira de Pesquisa Agropecuária. Unidade de Execução de Pesquisa de Ambiente Estadual de Dourados, MS. Milho: informações técnicas. Dourados, 1991. p.114-127 (EMBRAPA UEPAE. Circular Técnica, 20). 
SILVA, J.B. da. Controle de planta daninhas. In: Empresa Brasileira de Pesquisa Agropecuária. Recomendações técnica para o cultivo de milho. Brasília, 1993. p.129-142.

SILVA, J.B. da; BALDEZ, L.C.G. Controle pós-emergente de plantas daninhas na cultura do milho (Zea mays) com Atrazine + Metolachlor. In: CONGRESSO BRASILEIRO DE HERBICIDAS E PLANTA DANINHAS, 19. Londrina, 1993. Resumos. Londrina: SBHED, 1993. p.193-195.

SILVA, J.B. da; DUARTE, N.F. Manejo de plantas daninhas na cultura do milho. In: FANCELLI, A.L.; DOURADO-NETO, D. (Coord.) Tecnologia da produção de milho. Piracicaba: Publique, 1997. p.75-83.

SILVA, J.B. da; KARAM, D.; ARCHÂNGELO, E. R. Controle pós-emergente de plantas daninhas na cultura do milho com a mistura de Atrazine + Nicosulfuron. In: CONGRESSO NACIONAL DE MILHO E SORGO, 20., Londrina, 1996. Resumos. Londrina: IAPAR, 1996. p.251.

SILVA, H.P.; MENTEN J.O.M. Manejo integrado de doenças na cultura do milho In: FANCELLI, A.L.; DOURADO-NETO, D. (Coord.) Tecnologia da Produção de milho. Piracicaba: Publique, 1997. p. 40-56.

TOLEDO, V; BEGLIOMINI, E. Controle de plantas daninhas em plantio direto. In: GRUPO PLANTIO DIRETO. Guia para plantio direto. Ponta Grossa, Centralgraph, 2000. p.45-51. 
VELLOSO J.A.R.O.; NARDI C.A. Praticabilidade e eficiência agronômica do herbicida Atrazine em formulação oleosa, em pós-emergência inicial, no controle de plantas daninhas, na cultura do milho (Zea mays) In: CONGRESSO BRASILEIRO DE HERBICIDAS E PLANTA DANINHAS, 19. Londrina, 1993. Resumos. Londrina: SBHED, 1993. p.185-186.

VELLOSO, J.A.R.O; SOUZA, R.O. Controle de plantas daninhas no sistema plantio direto na palha. In: Plantio direto no Brasil. Passo Fundo. Aldeia Norte, 1993. p.61-75.

VICENTE, D.; SAWADA, E.M. Efeitos de herbicidas aplicados em pósemergência no controle de plantas daninhas e seletividade no milho (Zea mays), hibrido duplo Ocepar 720. In: CONGRESSO BRASILEIRO DA CIÊNCIA DAS PLANTAS DANINHAS, 21. Viçosa, 1997. Resumos. Viçosa: SBCPD, 1997. p.229.

WATANABE, C.M.; BALDEZ, L. C. G.; NISHIMURA, M.; PEREIRA, N. A.; HONDA, T.; CARDOSO, E. P.; FACCO, M. Avaliação da mistura pronta Atrazine + Metolachlor, aplicada em diferentes horários, no controle em pós-emergência das invasoras da cultura do milho. In: CONGRESSO BRASILEIRO DE HERBICIDAS E PLANTA DANINHAS, 19. Londrina, 1993. Resumos. Londrina: SBHED, 1993. p.140. 
7 Apêndice

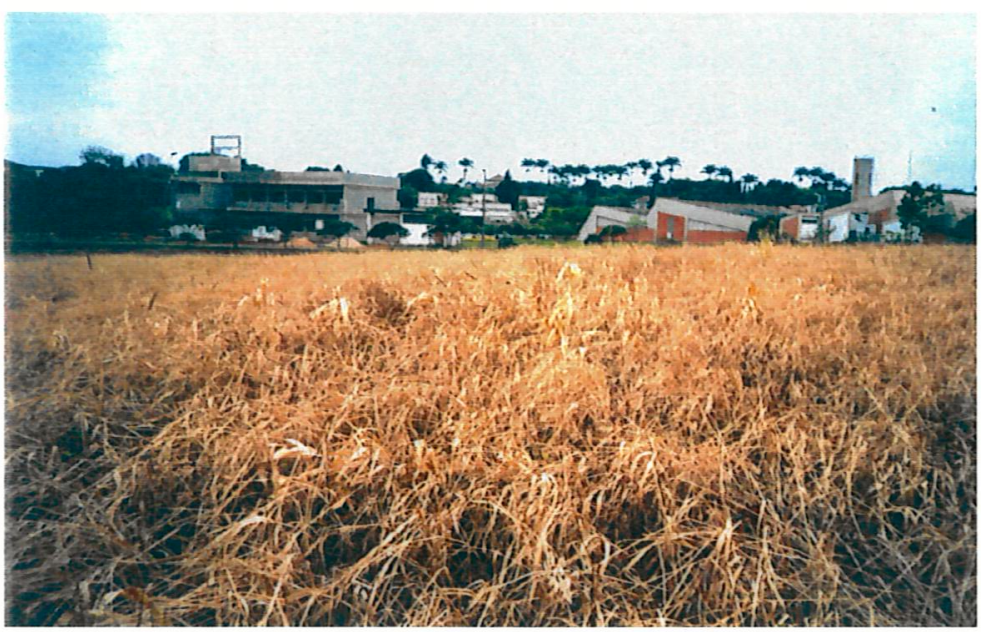

Figura 5. Área dessecada antes da semeadura, no sistema de plantio direto. Departamento de Produção Vegetal, ESALQ/USP.

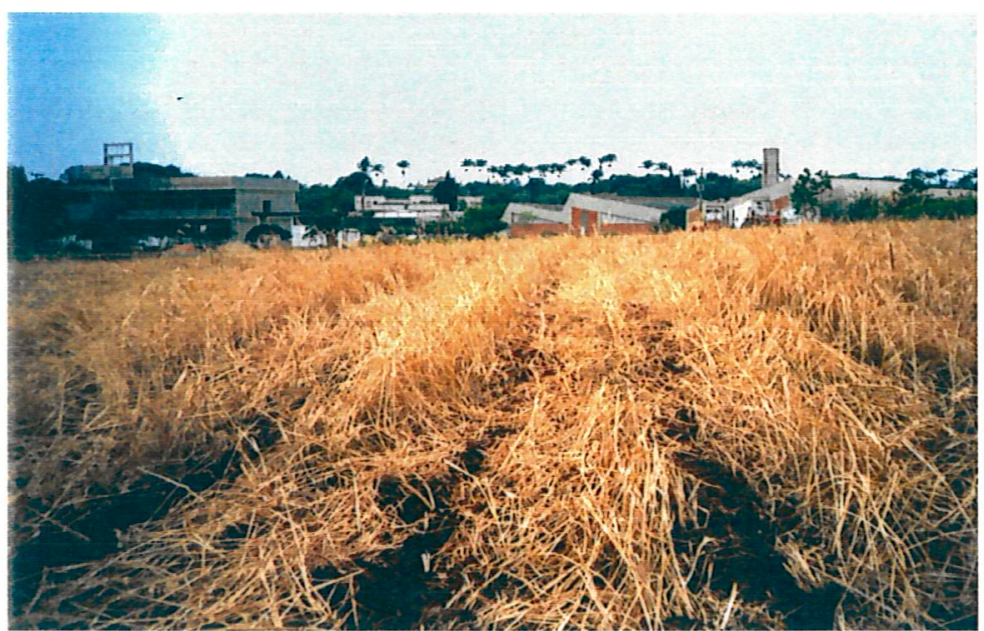

Figura 6. Semeadura da cultura de milho (híbrido Pioneer 3027), no sistema de plantio direto. 


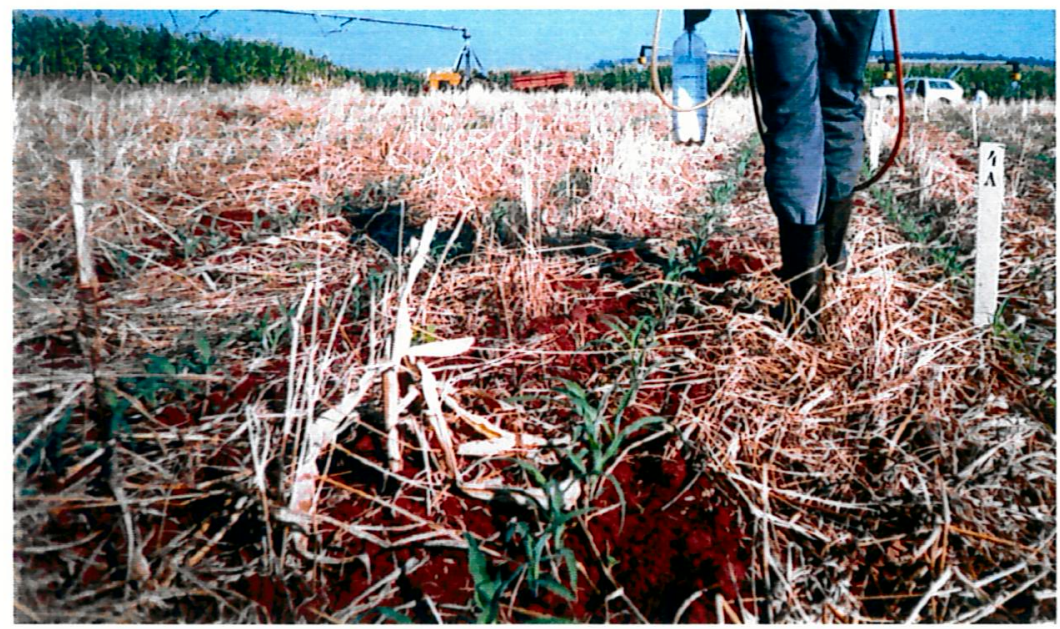

Figura 7. Aplicação dos herbicidas quando a cultura de milho apresentava duas folhas (estádio 0-1).

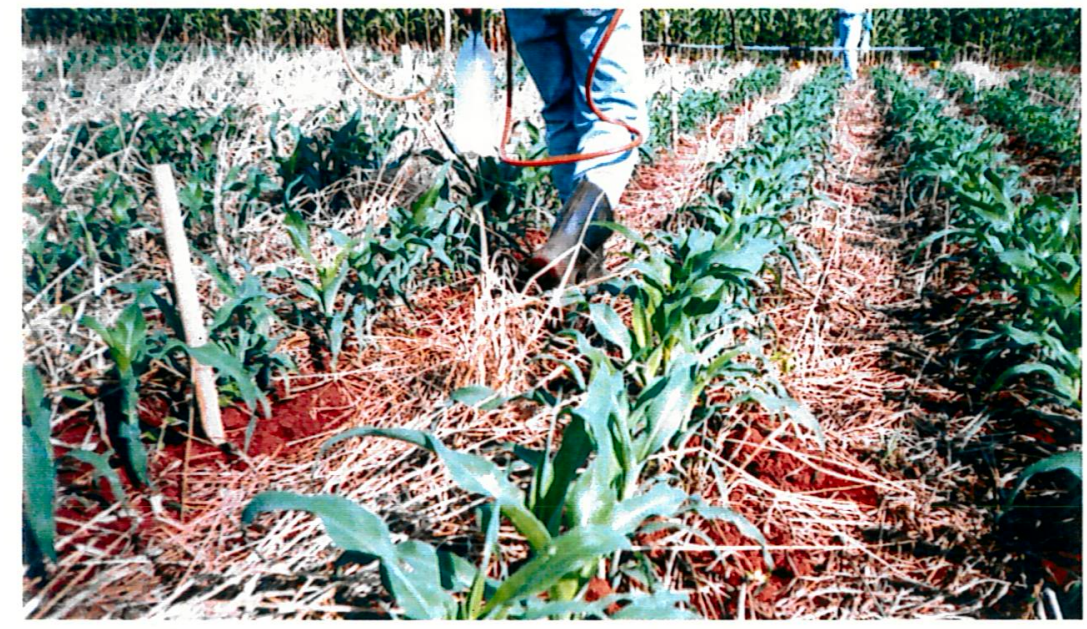

Figura 8. Aplicação dos herbicidas quando a cultura de milho apresentava quatro folhas (estádio 1). 


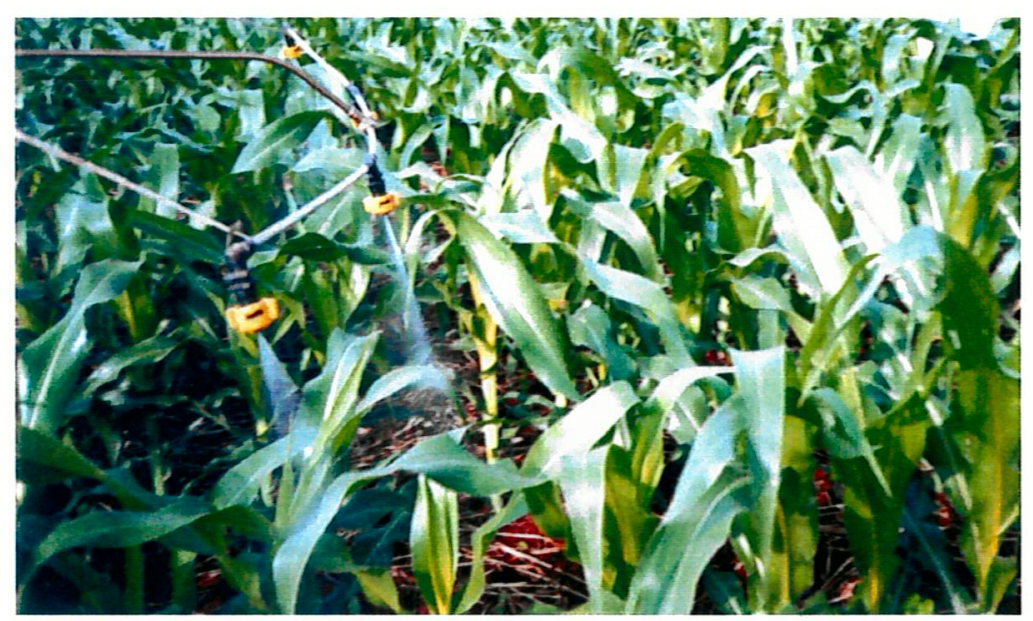

Figura 9. Aplicação dos herbicidas quando a cultura de milho apresentava oito folhas (estádio 2).

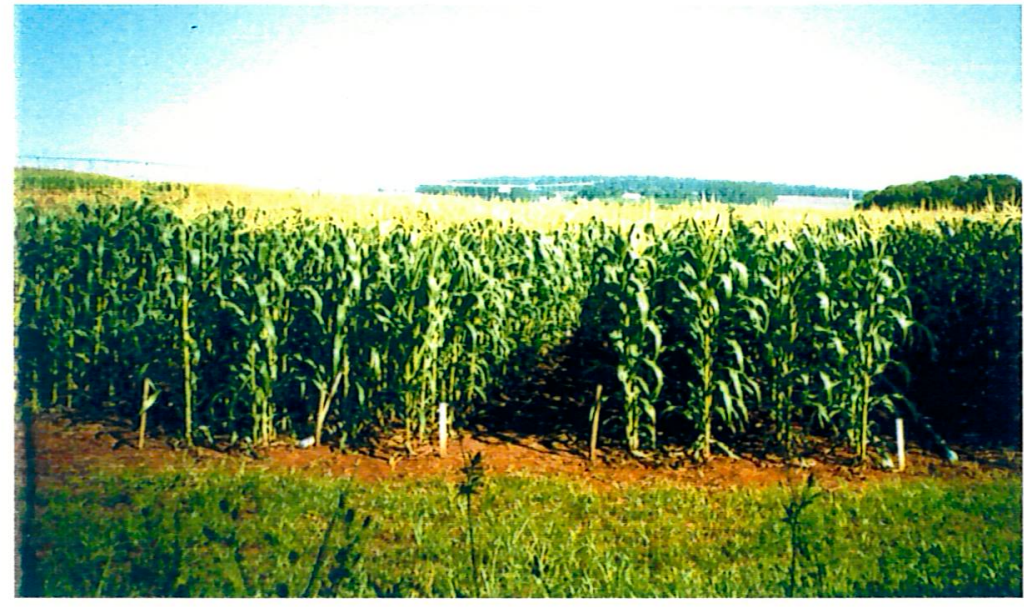

Figura 10. Visão da área experimental quando a cultura de milho se apresentava no florescimento. 